\title{
The importance of threshold in alluvial river channel geometry and dynamics
}

Colin B. Phillips ${ }^{1}$, Claire C. Masteller ${ }^{2}$, Louise J. Slater ${ }^{3}$, Kieran B. J. Dunne ${ }^{4}$, Simona Francalanci ${ }^{5}$, Stefano Lanzoni ${ }^{6}$, Dorothy J. Merritts ${ }^{7}$, Eric Lajeunesse ${ }^{8}$ and Douglas J. Jerolmack ${ }^{9,10, *}$

${ }^{1}$ Civil and Environmental Engineering, Utah State University

${ }^{2}$ Earth and Planetary Sciences, Washington University in Saint Louis

${ }^{3}$ School of Geography and the Environment, University of Oxford, Oxford, UK

${ }^{4}$ Earth, Environmental, and Planetary Sciences, Rice University

${ }^{5}$ Civil and Environmental Engineering, University of Florence

${ }^{6}$ Civil, Environmental and Architectural Engineering, University of Padua

${ }^{7}$ Earth and Environment, Franklin and Marshall College

${ }^{8}$ Universite de Paris, Institut de Physique du Globe de Paris, CNRS, F-75005, Paris, France

${ }^{9}$ Earth and Environmental Science, University of Pennsylvania

${ }^{10}$ Mechanical Engineering and Applied Mechanics, University of Pennsylvania

*e-mail: sediment@sas.upenn.edu

This paper is a non-peer reviewed preprint submitted to EarthArXiv. The article is in peer review at Nature Reviews Earth and Environment 


\title{
The importance of threshold in alluvial river channel geometry and dynamics
}

\author{
Colin B. Phillips ${ }^{1}$, Claire C. Masteller ${ }^{2}$, Louise J. Slater ${ }^{3}$, Kieran B. J. Dunne ${ }^{4}$, Simona \\ Francalanci $^{5}$, Stefano Lanzoni ${ }^{6}$, Dorothy J. Merritts ${ }^{7}$, Eric Lajeunesse ${ }^{8}$, and Douglas J. \\ Jerolmack ${ }^{9,10, *}$
}

${ }^{1}$ Civil and Environmental Engineering, Utah State University

${ }^{2}$ Earth and Planetary Sciences, Washington University in Saint Louis

${ }^{3}$ School of Geography and the Environment, University of Oxford, Oxford, UK

${ }^{4}$ Earth, Environmental, and Planetary Sciences, Rice University

${ }^{5}$ Civil and Environmental Engineering, University of Florence

${ }^{6}$ Civil, Environmental and Architectural Engineering, University of Padua

${ }^{7}$ Earth and Environment, Franklin and Marshall College

${ }^{8}$ Université de Paris, Institut de physique du globe de Paris, CNRS, F-75005, Paris, France

${ }^{9}$ Earth and Environmental Science, University of Pennsylvania

${ }^{10}$ Mechanical Engineering and Applied Mechanics, University of Pennsylvania

*e-mail: sediment@sas.upenn.edu

\begin{abstract}
Many cities and settlements are organized around alluvial rivers, which are self-formed channels composed of gravel, sand and mud. Much of the time alluvial river channels are oversized, in that they could accommodate greater water flow; yet during extreme storms they are woefully undersized, and potentially catastrophic flooding can occur. Considering widely varying hydroclimates, sediment supply, geologic constraints and varying vegetation, it is not altogether obvious that rivers should achieve an average channel geometry that is pattern stable - let alone predictable from theory. Yet, natural rivers follow remarkably consistent hydraulic-geometry scaling relations, that are reproduced in laboratory experiments. Starting with the constraint that channel formation requires that fluid stress exceeds the threshold for sediment entrainment, we review the explanatory power of threshold channel models. Moreover we explore how deviations from threshold channel theory relate to higher-order dynamics of fluid and sediment transport - essentially perturbations to the threshold state — clarifying misconceptions regarding model applicability. Finally, we demonstrate the utility of the threshold channel framework for understanding channel patterns and responses to variations in external forcing such as hydroclimate and land use. Accurate field determination of the entrainment threshold itself is a notorious problem, and emerges as a central challenge in further development and application of threshold channel theory.
\end{abstract}

Key points:

- The size and shape of a river channel both control and adjust to the flow of water and sediment within it, with consequences for flooding and ecological habitat.

- The question of what determines river-channel size and shape galvanized a quantitative revolution in geomorphology and its applications through "hydraulic geometry scaling", yet there is no generally accepted model.

- We consider the most prevalent models, and lay out the case that rivers are adjusted to the threshold of erosion for the most resistant material lining the channel.

- We demonstrate how the threshold-limited channel model represents a distillation of complex processes and variables, and provide a framework for its application in predicting mean channel size.

- The threshold-limited model may be beneficial for predicting how changes in hydroclimate and land use drive adjustments in the mean geometry of river channels.

Website summary: Alluvial rivers consist of channels formed by erosion and deposition of sediment; they are the continents' arteries of water, nutrients and commerce. This Review examines how the threshold for sediment entrainment controls the size, shape and dynamics of alluvial rivers. 


\section{Introduction}

1 The flow of water and sediment across terrestrial landscapes is concentrated in, and organized by, rivers. In this Review we examine the geometry of alluvial rivers, channels for which the bed and banks are composed of sediment transported by the river itself. As one traverses from steep mountain streams to the mouths of the world's great rivers, alluvial channel parameters span a staggering range of scales: slopes $(S)$ decrease from $10^{-1}$ to $10^{-6}$; widths $(W)$ increase from decimeter $\left(10^{-1} \mathrm{~m}\right)$ to kilometer scale $\left(10^{3} \mathrm{~m}\right)$; channel-filling water discharge increases by over nine orders of magnitude $\left(10^{-4}-10^{5} \mathrm{~m}^{3} / \mathrm{s}\right)$; and bed and bank sediments decrease from boulder $\left(10^{0} \mathrm{~m}\right)$ to clay $\left(10^{-6} \mathrm{~m}\right)$. Alluvial river formation can involve comparably large space and time scales: from the entrainment of a single sediment grain by a turbulent burst or particle collision ${ }^{1,2}$, to the evolution of continental-scale drainage networks and basin filling in response to climatic and tectonic forcing over millions of years ${ }^{3,4}$.

It is difficult to overstate the importance of alluvial rivers to the evolution of the Earth's surface and its inhabitants. On geologic timescales, alluvial rivers propagate and filter signals of climate and base level (e.g. sea level) change between sediment sources and sinks ${ }^{5-8}$. Alluvial rivers' stratigraphic signatures record the birth and demise of ancient mountain ranges, seas and basins ${ }^{4,9-11}$. Alluvial rivers are bioreactors that modulate nutrient and carbon cycles ${ }^{12-14}$, and networks for the flow of biomass. They have historically been a cornerstone of societal development because they provide reliable water sources, fertile soil to surrounding floodplains, shipping routes, hydropower, recreation, and habitat for aquatic species ${ }^{15-19}$. Living along rivers, however, comes at a cost. Catastrophic flooding destroys lives, crops and infrastructure ${ }^{18,20}$. Land-use changes associated with urbanization and agriculture - including the storage of water in reservoirs for energy production, flood control, and irrigation purposes - have drastically altered the delivery of nutrients, water and sediment to alluvial rivers ${ }^{21-25}$. The resulting erosion, flooding, and water-quality impairment have propelled a vicious cycle of damming, armoring and restraining rivers, which requires ever-increasing investments in mitigation and restoration projects ${ }^{26,27}$.

The challenges above lead to two central questions that helped to galvanize a quantitative revolution in fluvial geomorphology more than a half century ago ${ }^{28}$ : what determines the size of a river; and how is this size characterized? Two key principles developed to answer these questions: 'hydraulic geometry scaling, ${ }^{29}$ and 'geomorphic work' ${ }^{30}$ established the basis for relating bankfull channel geometry (width, depth and slope) and planform pattern ${ }^{31}$ to a 'characteristic' discharge ${ }^{32}$. The commonly observed power-law relations ${ }^{29,33-38}$, compiled from measurements around the world, have been taken to suggest that alluvial river size is determined primarily by hydraulic conveyance (Fig. 1). Debates have ensued, however, regarding both the universality of the scaling exponents and their meaning; vegetation, cohesive banks, hydroclimate, flow resistance and other regional variations have been reported to influence hydraulic geometry scaling relations ${ }^{39-43}$. This variation has been reduced, and physical insight gained, by recasting the observations in dimensionless form ${ }^{34,44}$. Yet the empirical relations alone have limited predictive power, and do not reveal the organizing principle(s) of alluvial rivers. They are suitably robust, however, to have tempted the development of several simplified and generalized models.

Early research linked fluid mechanics with alluvial channel geometry ${ }^{45-47}$ through the development of flow resistance relations in threshold canals, designed to convey water while never exceeding the entrainment threshold. Building on canal theory $46,48,49$, a family of models has been advanced in which sediment transport is formally treated as a mathematical 35 perturbation to the threshold state ${ }^{50-52}$. Though different in detail, these models indicate that alluvial rivers at bankfull organize 
their geometry such that fluid shear stresses at the channel center only slightly exceed the entrainment threshold. These "nearthreshold models" are physically rational, and appear to explain the first-order trends in hydraulic geometry of alluvial rivers providing an explanation for how alluvial rivers can transport sediment without destabilizing their banks ${ }^{44,52-54}$. This does not, however, indicate they are generally accepted. Researchers have presented evidence for a wide range of fluid stress states in alluvial rivers that appear to contradict the near-threshold condition ${ }^{55-57}$. Evidence of apparent deviation from near-threshold conditions has been attributed to factors not considered within the model: sediment supply, bed grain-size properties, vegetation, cohesive banks, and the influence of extreme events ${ }^{58-65}$. Yet, others have observed that such discrepancies may arise from mischaracterization of the threshold condition and the near-threshold model itself $\mathrm{f}^{6,52,66}$. Alternative models for hydraulic geometry have proliferated, based on: optimization of sediment transport ${ }^{67-71}$; feedback between flow resistance and channel form $^{72,73}$; and geotechnical stability of river banks ${ }^{74}$.

For the practitioner of river science or management, it is not obvious how to reconcile disparate claims regarding the veracity of these models. For the researcher, it may be unclear what kinds of data are needed to discriminate among competing models. Moreover, with the advent of increasingly sophisticated morphodynamic models that are capable of simulating flow and sediment transport in three dimensions $(3 \mathrm{D})^{75,76}$, one may rightly question the need for a simplified model of average channel geometry ${ }^{77}$. We contend, however, that a physically-based and simple model for alluvial channel geometry is an indispensable tool for understanding and managing rivers. Such a model can give insight on the most important controlling variables, provide a benchmark for numerical simulations, serve as an initial design criterion for channel restoration, provide first-order river geometry predictions in the absence of high-resolution topography or in headwater streams where topographic data resolution limits currently exist, predict channel response to changes in land use and hydroclimate, and be easily implemented in landscape evolution and conservation models.

A viable theory for alluvial channel geometry must: (i) explain, to leading order, the shape of channel cross sections; (ii) explain how the channel maintains this state under natural (highly stochastic) forcing; and (iii) directly link channel shape to the mechanics of sediment transport. While a multitude of models are capable of predicting channel cross-section geometry, only the near-threshold model has been demonstrated to achieve all three criteria ${ }^{6,51,52}$. This Review examines the physical basis and surprising explanatory power of the near-threshold model, and attempts to clarify misconceptions regarding its formulation and application to natural rivers. We first describe the nature and extent of hydraulic geometry scaling. We then introduce the family of near-threshold models, and compare them to other alternative frameworks. We demonstrate the application of the near-threshold model to dynamic rivers, and outline current challenges in validation and prediction. Finally, we examine alluvial river responses to changes in hydroclimate and land use through the near-threshold lens. In staking out the scope of this Review, we point the reader toward previous studies that we view as complementary and informative, on the following topics: sediment transport ${ }^{78}$; channel morphology and morphodynamics ${ }^{77,79}$; a review of hydraulic geometry ${ }^{37}$; and river restoration and management practices $27,80,81$. Within this Review we do not consider bedrock rivers, which require a phase transition breaking or dissolving rock - for channel formation and evolution ${ }^{82,83}$. Strong similarities exist between alluvial and bedrock river hydraulic geometry ${ }^{84-87}$, indicating that this Review may be of interest for those studying the role of rivers in setting the pace and style of mountain erosion ${ }^{88}$. 


\section{The basis for hydraulic geometry scaling}

\section{Orders of channel behavior}

We first propose a conceptual framework to organize the patterns and dynamics of alluvial rivers within a hierarchy of models, in terms of their order of complexity. We relate this hierarchy of channel behaviors to the order of approximation of the fluid and sediment transport equations. Models developed for one order often, by necessity, neglect processes and behaviors at other orders (Fig. 2). A zeroth-order model for alluvial rivers addresses the questions of existence and stability; under what conditions does a river form and what end state does this produce? Linear stability theory can be used to predict the onset and initial scale of channel formation ${ }^{89-91}$. Because higher-order interactions between perturbations are neglected, these models cannot describe the nonlinear feedbacks that ultimately stabilize channels under the imposed boundary conditions of sediment and water fluxes. We consider a first-order description of alluvial rivers to be the average geometry (width, depth, slope) and grain size; thus, this corresponds to the first moment in statistical distributions of these variables. We posit that a first-order (and essentially 1D) model for flow and sediment transport can predict first-order features, while placing no constraint on the nature of variation around the mean ${ }^{52}$. Second-order patterns in alluvial rivers are commonly driven by secondary flows ${ }^{92}$ where deviations from straight-channel configurations and spatial oscillations within channel geometry cause streamlines to follow curvilinear paths generating secondary currents; 2D vertical or horizontal variations in fluid stress contribute to and are influenced by bed morphology (dunes and bars), which may preferentially sort sediment ${ }^{93}$. We hypothesize that the second moment in the distributions of width, depth, slope and grain size becomes relevant for these patterns. Models developed to describe second-order patterns and flows, such as meander growth models ${ }^{94-98}$, typically fix first-order patterns such as mean channel geometry. Finally, we suggest that a third-order description (Fig. 2) of alluvial rivers corresponds to a 3D treatment of the flow and sediment transport fields. At present such a treatment is not analytically tractable, and thus the relevant models are full 3D numerical simulations ${ }^{99,100}$.

\section{Bankfull Hydraulic Geometry}

"Bankfull Hydraulic Geometry"29 is the first-order description of alluvial channels that we examine here. This describes the average width $\left(W_{b f}\right)$, depth $\left(H_{b f}\right)$ and surface slope $(S)$ of the flow associated with a discharge $\left(Q_{b f}\right)$ that fills the channel to the top of its banks (Fig. 1c; Box 1). One reason for this choice is that it provides a relative reference point for comparison of cross sections among different rivers, or for the same river at different locations downstream ${ }^{29}$ (Fig. 1a-d). Another reason is that bankfull flows typically activate channel dynamics through significant sediment transport (see below; Box 1), and therefore they are relevant for setting the size and shape of the river ${ }^{30,34,36}$. Traditional "Hydraulic Geometry Scaling" refers to the observed power-law relations between bankfull geometry and discharge: $W_{b f}=a_{W} Q_{b f}^{b_{W}}, H_{b f}=a_{H} Q_{b f}^{b_{H}}$ and $S=a_{S} Q_{b f}^{b_{S}}$, where the coefficients $a$ and exponents $b$ are determined from empirical fits to data. Decades of data compilations from surveyed river cross sections ${ }^{29,34,38}$ have firmly established the existence of power-law trends (Fig. 1e), but also found variations in the reported exponents across different physiographic provinces ${ }^{43}$. This indicates that the set of variables considered provides an incomplete description, and that a physically-informed non dimensionalization of the problem may reduce scatter.

Channel formation requires entrainment of bed and bank material by a gravity-driven flow, suggesting that the following additional parameters should be considered at a minimum: median grain size of mobile bed material, $D_{50}$; relative submerged density, $R=\rho_{s} / \rho-1$ where $\rho_{s}$ is sediment density and $\rho$ is fluid density; and acceleration due to gravity, $g$. The dimensionless 
discharge is $Q_{*}=Q_{b f} / \sqrt{\operatorname{Rg} D_{50}^{5}}$, and the dimensionless hydraulic geometry scaling relations become ${ }^{34,44,53}$ :

$$
W_{b f} / D_{50}=\alpha_{W} Q_{*}^{\beta_{W}}, \quad H_{b f} / D_{50}=\alpha_{H} Q_{*}^{\beta_{H}}, \quad S=\alpha_{S} Q_{*}^{\beta_{S}}
$$

The dimensionless relations (Eq. 1) indeed collapse a significant portion of the scatter (Fig. 3), and are therefore utilized here.

Numerous compilations of data have been reported that may be used to fit and generally validate Eq. (1) ${ }^{55,56,66}$. A consideration of the nature of these data is in order. Data compilations of hydraulic geometry typically report, for each site, average values of bankfull depth and width from a few cross-sectional surveys, a longitudinal profile of the river bed, and a statistically random sampling of the river-bed grain-size distribution ${ }^{101}$. Variation and ambiguities exist in methods for determining bankfull conditions as topographic indices are not always prevalent or multiple indicators exist ${ }^{102,103}$; the data used here generally represent river reaches where morphological breaks in channel cross section indicate the bankfull conditions. An under utilized source in such compilations is the vast network of stream gages maintained by the United States Geological Survey (USGS), in which 'stage' and discharge are determined for a wide range of flows in surveyed channel cross sections. Stream gages are intentionally placed at locations where channel geometry is relatively 'simple' and stable ${ }^{104-106}$, typically precluding braided rivers and meander bends; such preclusion may introduce some bias into measured geometries. However, the bias towards stable cross sections indicates that these data may be perfectly suited for determining the first-order channel behavior. To date, USGS gages represent the largest quality controlled publicly-available database for examining hydraulic geometry and hydroclimate ${ }^{107-109}$. Accordingly, observations from North America, and particularly the USA, are typically over represented in 'global' alluvial river hydraulic geometry compilations ${ }^{66}$.

Here we follow recent work and utilize a compiled database of 1,662 cross sections ${ }^{110}$ from throughout various river networks built primarily on USGS gages and independent studies of river processes, while incorporating to a lesser extent natural rivers from outside the USA and a subset of laboratory experiments ${ }^{52,53}$. Slope and grain size are not reported within the river transect measurements, and must be determined from complementary reports and/or independent studies that may utilize differing methodologies. Accordingly, we expect some irreducible degree of scatter from indeterminate methodological error and natural heterogeneity. Despite these shortcomings, the observed trends for dimensional and dimensionless width and depth are nonetheless remarkably clean across the entire range of $Q_{*}$ in the database (Fig. 1e and 3a). Given the small variation in $R$ for natural rivers (and constant $g$ ), these data indicate that the width and depth of rivers are strongly determined by hydraulic conveyance. Slope, however, is different: its correlation with $Q_{*}$ is much more scattered and, moreover, gravel- and sand-bedded rivers separate into two distinct clouds (Fig. 3c). These data require an additional variable, beyond discharge and grain size, to account for observed slope. It has been proposed that sediment supply, $Q_{s}$, is the missing factor ${ }^{5,34,111}$; however, this parameter is rarely reliably reported as it remains difficult to measure. Others have suggested that the timescale for slope adjustment is very long (compared to width and depth) due to the large volume of sediment that must be reworked ${ }^{77}$, and thus that the scatter reflects a lack of stationarity in slope. Any further advance in interpreting the hydraulic scaling relations (Eq. 1) requires a model. 


\section{The importance of threshold: A minimal model for river channel geometry}

\section{Sediment transport as a perturbation to the threshold state}

Alluvial river channels are a consequence of the feedback between flow and form: the form of a river determines the flow within it under an imposed discharge, but the time-integrated effects of flow — and the associated sediment transport — sculpt channel form. The formulation of an elementary model for hydraulic geometry rests on three key principles. First is separation of scales: fluid and sediment transport adjust to channel form rapidly, while channel form adjusts slowly to transport. This allows for quasi-steady and quasi-uniform flow assumptions for estimating the fluid boundary stress ( $\tau$, see Box 2 ), that greatly simplify the problem ${ }^{112}$. Second is the presumption of stationarity: river channels achieve a stable geometry in a statistically averaged sense, and this geometry satisfies the stationary solution of mass conservation - i.e., no net erosion or deposition. Many studies refer to this state as "dynamic equilibrium"113. Third is the constraint of threshold: a river must entrain sediment locally to form a channel, and a channel will stop evolving if it reaches the threshold entrainment stress $\tau_{c}$ everywhere along its boundary ${ }^{53}$. The latter state, associated with no sediment transport, is the well known optimal solution for canal design ${ }^{33,53,114}$.

In the limit of no sediment supply, experiments with laminar and turbulent flow demonstrate that channels evolve to a threshold condition with a cross section in the shape of a cosine ${ }^{46,48,114}$ — where fluid and gravitational stresses everywhere on the bed are balanced by friction. This reduces the solution for the stable threshold channel to a hydraulic problem: with expressions for fluid-mass conservation and flow resistance, the shape and slope of the channel can be predicted if one imposes values for: discharge, sediment properties $\left(D_{50}, R\right)$ and flow resistance $\left(C_{f}\right)$ (Box 2). In the absence of bed forms, flow resistance arises primarily from grain-scale roughness and hence $C_{f}$ may be estimated from $D_{50}{ }^{53,114}$. Alluvial rivers are not canals of course; they regularly transport their bed sediment, and therefore experience fluid stresses in excess of threshold. Yet many alluvial rivers maintain stable banks (on average), which would appear to require fluid stresses at or below threshold. Gary Parker referred to this problem as the "stable channel paradox" ${ }^{50}$, and presciently stated "[such] paradoxes are often resolved in terms of singular perturbation analysis". This suggests that sediment transport may be treated, conceptually and mathematically, as a perturbation to the threshold state; and that the corresponding average stress condition is $\langle\tau\rangle=(1+\varepsilon) \tau_{c}$, where $\varepsilon \ll 1$. We refer generically to the model class based on a perturbation approach as the " $1+\varepsilon$ model". Indeed, trend lines in hydraulic geometry scaling of alluvial rivers follow predictions of the threshold channel theory (Fig. 3a), but with an offset that indicates a formative fluid stress that is above threshold ${ }^{44}$.

Parker' ${ }^{50}$ original $1+\varepsilon$ model built directly on the hydraulic stable canal theory, and assumed ideal conditions including: a straight channel, constant imposed discharge and $C_{f}$, and uniform grain size along the bed and banks. It was formulated for gravel rivers, in which sediment moves purely by bed load. Parker proposed that lateral diffusion of momentum, from the channel center toward the margins due to turbulence, is the perturbation that solves the stable channel paradox. The solution describes a channel with stable banks $\left(\tau \leq \tau_{c}\right)$, and active sediment transport in the channel center $\left(\tau>\tau_{c}\right)$. This model predicts a width-averaged formative shear stress $\langle\tau\rangle \approx 1.2 \tau_{c}$, i.e., $\varepsilon \approx 0.2$. It is important to note that the value for $\varepsilon$ depends on specific model choices, such as the turbulent closure scheme and flow resistance relation. All reasonable choices, however, would produce a near-threshold channel.

In Parker's formulation, channel geometry is fundamentally determined by hydraulics. An alternative model was recently proposed by researchers from the Institut de Physique du Globe de Paris (IPGP), in which channel shape, under laminar flow 
conditions, is adjusted to achieve a balance between lateral diffusion of bed-load flux toward the channel margins, and inward sediment motion due to gravity ${ }^{51}$. In this formulation, raising the imposed sediment discharge drives increases in channel aspect ratio $(W / H)$ and slope, away from the threshold state associated with no sediment flux (Fig. 3e). Experiments show, however, that a channel will not tolerate a large increase in sediment discharge; instead, a single channel destabilizes into multiple near-threshold threads akin to a braided river (Fig. 3d) ${ }^{53,115-118}$. In this manner, the threshold state is like the critical angle of a sandpile ${ }^{119}$ : alluvial rivers can adjust their slope and channel geometry when driven by an imposed sediment load, but they always remain close (i.e., $1+\varepsilon)$ to the threshold state.

The two $1+\varepsilon$ models above propose different perturbations to the threshold state to explain alluvial rivers. However, both models are founded on the observation that an alluvial river adjusts its cross section to a state in which bed-load transport is accommodated in the active channel center where fluid stress slightly exceeds threshold, and diminishes laterally to zero on the banks. We believe that these models complement, rather than contradict, each other; Parker's approach neglects lateral bed-load flux arising from a concentration gradient in sediment transport, while the IPGP model ${ }^{51}$ neglects lateral fluid-momentum flux arising from a gradient in stress. A more complete solution, which includes both effects, will likely have greater power for predicting alluvial channel shape ${ }^{51}$. Nevertheless, the near-threshold constraint that $\langle\tau\rangle=(1+\varepsilon) \tau_{c}$ is sufficient to close the set of governing equations for a first-order model of channel geometry. As we shall see, this model has surprising explanatory power when applied judiciously.

\section{Modifications and generalizations of near-threshold models}

One person's boundary condition is another person's model. The near-threshold models above typically impose the following variables as fixed boundary conditions: grain size, sediment discharge, threshold-fluid stress and flow resistance (among others). In natural rivers, however, all of these parameters - where measured - can and do adjust to achieve a channel geometry consistent with the near-threshold state. Here we briefly summarize relevant studies that explicitly examine these adjustments, allowing generalization of the $1+\varepsilon$ model.

The fluid entrainment threshold is typically described by the dimensionless Shields stress, representing the ratio of fluid forces over the submerged weight of a particle: $\tau_{c}^{*}=\tau_{c} /\left(\left(\rho_{s}-\rho\right) g D_{50}\right)$. For loose and non-cohesive grains, $\tau_{c}^{*}$ is primarily a function of near-bed turbulence and its mean value may be estimated from the Shields curve ${ }^{120,121}$. Variation in flow resistance can result in apparent changes in $\tau_{c}^{*}$, if an appropriate form drag correction is not applied when estimating the boundary stress $^{122,123}$. More vexing are the factors influencing the resistance to grain motion — not accounted for in the Shields curve that can significantly alter $\tau_{c}^{*}$ in ways that are difficult to predict. Among these are: bed slope effects ${ }^{124-127}$; bed compaction and sediment structures/morphology ${ }^{128,129}$, particle shape and size distributions ${ }^{130,131}$, and cohesion ${ }^{132-137}$. Challenges in determining $\tau_{c}^{*}$, and their contributions to uncertainty in alluvial channel geometry, are described below. Here we summarize a recent approach, however, that shows how the $1+\varepsilon$ model can be generalized to heterogeneous natural rivers - if the entrainment threshold can be determined properly. It is common to observe a significant difference in $\tau_{c}$ between the bed and banks for natural alluvial channels, where the bed is usually composed of sand or gravel and the banks are comprised of cohesive materials (mud). While entrainment thresholds for mud vary widely as functions of clay and organic content, temperature, and chemistry ${ }^{138-142}$, in general gravel $\left(D_{50}>1 \mathrm{~cm}\right)$ has a larger $\tau_{c}$, and sand $\left(D_{50}<1 \mathrm{~mm}\right)$ has a smaller $\tau_{c}$, than naturally consolidated mud. Dunne and Jerolmack ${ }^{52}$ proposed an extension of Parker's model that they called the "threshold-limited 
channel" model: it posits that alluvial rivers adjust their geometry to the threshold fluid entrainment stress of the most resistant material lining the channel, i.e., $\langle\tau\rangle=(1+\varepsilon) \tau_{c \max }$. In practice, gravel-bed rivers are adjusted to $\tau_{c}$ of the gravel bed, while sand-bed rivers are adjusted to $\tau_{c}$ of the muddy banks (when present). This empirically validated model explains how sand-bed rivers maintain stable banks, even though boundary shear stresses are far in excess of $\tau_{c}$ for bed material (Fig. 4).

The importance of flow resistance, in terms of channel hydraulics and sediment transport, has long been recognized ${ }^{45,47}$. The boundary stress available to transport sediment is only a fraction of the total fluid stress; the rest, termed form drag, is dissipated by turbulence arising from channel roughness at all scales — from grain, to bed form, to bank curvature ${ }^{143,144}$. Francalanci et al. ${ }^{72}$ proposed a model in which the overall flow resistance of the channel is determined by the coupled solution of the flow in the bank region with the channel center, which results in channel adjustment to the entrainment threshold of the bank material. They showed how transverse undulations in the river bank can modulate the boundary shear stress, and that accounting for this effect improves predictions of hydraulic geometry, allowing a remarkable collapse of the dimensionless data concerning both gravel and sand-bed rivers with cohesive banks. This approach may be considered to be an elaboration of the $1+\varepsilon$ model.

\section{Alternatives to the $1+\varepsilon$ model}

A distinctly different near-threshold model was recently proposed, wherein river-bank height is limited by the threshold for gravitational collapse ${ }^{74}$. In this scenario, the angle of repose of bank materials — rather than the fluid threshold $\tau_{c}-$ sets the condition for channel adjustment. This model does not attempt to explain the fluid stress or sediment transport states within the channel. Nevertheless it predicts changes in channel geometry as a function of bank cohesion that are similar to expectations from the fluid stress models.

A broader and more pervasive class of models, based on "extremal hypotheses", has been proffered as the primary alternative to near-threshold models for explaining hydraulic geometry scaling. There is some physical basis for proposing an extremal hypothesis as a closure scheme: often in problems that can be cast in terms of conservation of energy, there is a unique system configuration that minimizes energy or maximizes entropy ${ }^{145,146}$. In classical physics problems, this configuration may be formally derived from a well-posed mechanical or thermodynamic constraint ${ }^{147}$. For rivers, the entrainment threshold is one such mechanical constraint; yet, models that invoke extremal hypotheses do not formally apply this constraint. Researchers have posited that rivers adjust their channel geometry to maximize flow resistance ${ }^{67,68}$, maximize entropy ${ }^{69}$, or maximize sediment transport $^{148,149}$. There is, however, no physical basis for predicting this 'optimal' river configuration; one can only assert that the observed state of a river is optimal. Recent developments in the mathematical theory of ramified optimal transport, which seeks solutions that minimize transportation $\cos ^{150}$, may eventually yield a more formal treatment for routing of water and sediment by rivers ${ }^{151}$ — and, consequently, their associated hydraulic geometry.

\section{Application of the near-threshold model to dynamic rivers}

Recent work has shown how the $1+\varepsilon$ model — which describes an idealized channel with static banks — can also describe the expected (average) channel geometry of dynamic natural alluvial rivers ${ }^{52}$. Correct application of the near-threshold model requires (i) accurate parameterization of variables that serve as model inputs, and (ii) appropriate averaging over higher-order behaviors (and their associated statistical moments). At least some of the apparent discrepancies reported between $1+\varepsilon$ model 
predictions, and observed hydraulic geometry, appear to be due to error arising from these two issues ${ }^{66}$.

\section{The importance of parameterization}

We first consider gravel-bed rivers; based on the threshold-limited channel model, we assume that bank composition may be neglected to first order ${ }^{54}$. The bankfull Shields stress $\left(\tau_{* b f}\right)$ values in the global database cluster around $\tau_{c}$ predicted using the Shields curve; the scatter around this trend, however, is more than an order of magnitude (Fig. 4a). These data would appear, at first blush, to suggest that some gravel-bed rivers sustain bankfull shear stresses of almost $10 \tau_{c}$ — conditions for which bed material could be suspended — while others fall below the entrainment threshold at bankfull. Hydraulic geometry scaling is correctly predicted by the $1+\varepsilon$ model, but with similarly large scatter around the trend (Fig. 3ab). There is mounting evidence $^{6,66}$ that these discrepancies arise primarily from mis-estimates of $\tau_{c}$. Determining the threshold entrainment stress is a notorious problem ${ }^{152}$; there is not even a single agreed upon definition of threshold ${ }^{152,153}$. While it is now well known that the Shields curve is inadequate for many field applications ${ }^{125,127,154}$, alternative formulations are empirical and have their own issues. For example, widely used empirical relations between $\tau_{c}^{*}$ and channel slope can produce systematic errors, when compared to in-situ estimates of $\tau_{c}^{*}$ determined from bed-load flux measurements ${ }^{66}$. Using measured (rather than modeled) threshold values, it was found that $\left\langle\tau_{b f}\right\rangle=1.19 \tau_{c}$ - remarkably close to the Parker model solution of $\left\langle\tau_{b f}\right\rangle=1.2 \tau_{c}$. Moreover, scatter was reduced to the range $\tau_{c} \leq\left\langle\tau_{b f}\right\rangle<2 \tau_{c}$ - indicating that bed material should move exclusively as bed load, in accordance with observations ${ }^{66,155}$. Unfortunately, measuring $\tau_{c}$ is laborious and error prone. As a consequence, only a small fraction $(<8 \%)$ of gravel-bed rivers in the global database have estimates of $\tau_{c}$. Nevertheless, this example shows how some of the apparent deviation from the $1+\varepsilon$ model is not due to any shortcoming of the model itself, but rather a consequence of improper parameterization of input variables.

Based on the threshold-limited channel model, Dunne and Jerolmack ${ }^{52}$ stated that "the cross-sectional geometry of [sandbed] rivers is set by the threshold stress of cohesive bank-toe material, which forms the structural anchor of the riverbank". In this view, the large deviations of sand-bed rivers from threshold — up to $100 \tau_{c}$ of the sandy bed material — do not invalidate the $1+\varepsilon$ model, but instead demonstrate the necessity of characterizing bank materials. In-situ measurements of $\tau_{c}$ for cohesive bank-toe materials are, unfortunately, exceedingly rare. Empirical relations between $\tau_{c}$ and silt/clay content can provide only order-of-magnitude estimates, and still require determination of bank-toe material composition ${ }^{54,156}$. In the few examples where the appropriate $\tau_{c}$ could be measured or estimated, however, observed $\left\langle\tau_{b f}\right\rangle$ and hydraulic geometry scaling of sand-bed rivers are in remarkably good agreement with predictions of the $1+\varepsilon \operatorname{model}^{52}$ (Fig. 4ab).

A related problem is the adequate determination of flow resistance and form drag. Due to the complexities of boundary layer turbulence, form drag must be estimated from empirical relations. Data compilations indicate that flow resistance at bankfull varies by one order of magnitude across a wide range of alluvial rivers ${ }^{54}$. Although this variation is smaller than other factors $\left(Q, D_{50}, S\right.$, etc.), assuming a fixed value for $C_{f}$ introduces significant scatter around the first-order trends in channel geometry $^{52,53}$. Francalanci et al. ${ }^{72}$ determined that form drag, arising from river-bank macro-roughness elements (bumps) and grains, dissipates $60-70 \%$ of the available fluid stress. As a consequence, rivers with stable cohesive banks and mobile beds are narrower and deeper than one would expect if form drag were neglected. Francalanci et al. ${ }^{72}$ determined empirical form-drag corrections, that reduced scatter in hydraulic geometry scaling relations. Similar to measuring threshold itself, in-situ determinations of form drag for each river would likely improve the agreement of observations with the $1+\varepsilon$ model. Resolving 
the sensitive dependence of turbulent momentum dissipation on complex boundaries is of fundamental importance for river hydraulics - but is also clearly beyond the scope of a first-order model for hydraulic geometry.

One question that arises in the application of the $1+\varepsilon$ model is whether channel slope is an input parameter or a model output. Both the Parker ${ }^{50}$ and IPGP ${ }^{51}$ models for gravel-bed rivers derive stationary solutions for channel slope, width and depth as functions of water and sediment discharge. However, solutions for width and depth can be rearranged to depend only on hydraulic factors - and not sediment discharge - if channel slope is imposed as an input parameter (Box 2). Hydraulic geometry data show that width and depth are well predicted by hydraulic conveyance, while the large scatter in slope (Fig. 3c) suggests an additional unmeasured factor — presumably sediment discharge — is required. Another possible factor is time, which of course is neglected in stationary solutions. Sediment transport models, that couple channel geometry to long-profile evolution via sediment mass conservation, predict that the timescale of slope adjustment may be on the order of millenia much larger than the decadal timescales of width and depth adjustment ${ }^{5,77,111,157,158}$. This separation of scales suggests that slopes of many natural rivers are not stationary; i.e., they may still be adjusting to modern water and sediment loads. This change may be slow enough, however, to be considered quasi-steady in terms of hydraulic geometry; i.e., width and depth may adjust in lockstep with changes in slope. Practically, this means that on engineering timescales slope should be treated as an input parameter to the $1+\varepsilon \operatorname{model}^{52}$; it is certainly easier to measure than sediment discharge. On geologic timescales, however, alluvial rivers set their own slope through regrading of valleys and meandering.

\section{The importance of averaging}

Given a constant imposed water discharge above the entrainment threshold, a channel will develop a (statistically) stationary geometry that just contains this flow ${ }^{51,114,159}$. Natural rivers, however, experience a wide range of discharges; most are well below bankfull, while occasional floods can be well above ${ }^{6}$. This raises a fundamental question: is bankfull discharge merely a useful reference point for hydraulic geometry comparisons, or is it a channel-forming flow condition with physical significance? The seminal work of Wolman and Miller $^{30}$ provided an elegant conceptual framework for answering this question. They reasoned that channels are adjusted to the flow of 'maximum geomorphic work': the stress whose product of frequency of occurrence, and intensity of sediment transport, moves the most sediment in the long-time limit. Large floods have high transport intensity but low frequency, while frequent low flows that do not exceed threshold do no work in moving material; it is intermediate stresses, with low transport intensity and moderate frequency, that do the most work in shaping the channel. Empirically, it has been demonstrated that $Q_{b f}$ also corresponds to the stress of maximum geomorphic work; in other words, the bankfull flow indeed appears to generally be the channel-forming discharge ${ }^{6,160-162}$. How is this achieved? To answer this question one must understand how water discharge is converted into boundary shear stress (Box 1). Discharge may be considered as a forcing condition on the river, determined by hydroclimate and drainage area. The frequency-magnitude distributions of river discharge, determined from long term gaging stations, show immense variation across climatic gradients, whereas the choice of bed-load transport equation produces less error in the estimate of the effective discharge ${ }^{163}$. In temperate rivers, discharge distributions are typically thin tailed, and $Q_{b f}$ has a recurrence interval of 1-2 years; while in arid regions discharge distributions can be heavy-tailed, and the recurrence interval of $Q_{b f}$ may be considerably longer ${ }^{164}$. Since flows below the entrainment threshold do not modify channel geometry, one must consider only the distributions of fluid stresses exceeding critical for the most resistant material (i.e., $\tau>\tau_{c}$ ). These distributions show a remarkably different behavior from 
discharge; they follow a thin-tailed distribution often well-described by an exponential function whose average value coincides with the bankfull discharge ${ }^{6,52,165}$. This occurs because the boundary stress that results from an imposed water discharge is determined by channel shape and flow resistance; i.e., $Q$ is imposed by watershed hydrology, but $\tau$ is an intrinsic property of the channel. For flow within the channel $\left(Q<Q_{b f}\right)$ we expect that flow depth, and hence $\tau$, increases nearly linearly with $Q$. Once $Q$ exceeds $Q_{b f}$, however, flow spreads across the floodplain and $\tau$ increases much more slowly with $Q$ (Box 1). This results in a rapid decline in the frequency of high stresses as flows exceed bankfull. The threshold constraint on channel organization is central here: river banks destabilize, and widen the channel, with increases in boundary stress above threshold — producing a negative feedback that keeps the channel in a near-threshold state ${ }^{159}$. The transformation of widely varying discharges into a common thin-tailed distribution of excess shear stresses has been termed the 'critical filter' ${ }^{6}$. It is a logical consequence of the organization of alluvial rivers to a near-threshold state, and justifies the use of a single bankfull discharge value in the application of the $1+\varepsilon$ model for hydraulic geometry.

The above should not be interpreted to mean that rivers do not respond to flows larger or smaller than bankfull, or experience temporal variations in erosion and deposition ${ }^{65}$. But in the context of hydraulic geometry (Fig. 1e), such variability represents fluctuations about some suitably-averaged, stationary mean state. These dynamics can correspond to large individual floods ${ }^{64}$, seasonal or cyclical variations in flow and sediment supply ${ }^{109}$, meander cutoffs, collapse of slump blocks into the channel, and myriad others. To maintain a stable mean geometry, deviations from this state must be compensated by others; and indeed there is emerging field documentation of such compensatory behavior. Sediment transport associated with smaller, frequent floods can act to smooth over perturbations to channel geometry created by large, rare floods ${ }^{63,166}$. The banks of a meandering river have been observed to migrate independently from each other at the flood to annual scale, but erosion on one bank is counterbalanced by deposition on the other such that river width is constant at decadal timescales ${ }^{167}$. These observations help to calibrate our expectation of the temporal averaging required for application of the $1+\varepsilon$ model. We posit that a reasonable averaging time must include several bankfull flow events, a notion that is supported by recent modeling results ${ }^{157}$. For temperate rivers this averaging timescale is on the order of a decade, but could be much longer within arid environments or comparatively shorter in flood-rich rivers ${ }^{6,165}$.

We now consider averaging over spatial variability in channel morphology. Dunes, bars and meander bends create systematic variations in channel width, depth, slope and grain size - variations absent within a first-order hydraulic geometry model. The length scales of these features should inform the spatial scales required for averaging ${ }^{52,168}$. Despite these sources of variability, a first-order model of channel geometry can still provide useful information. For example, measured channel widths of a meandering river exhibited a wide statistical distribution, but the modal value was well predicted by the $1+\varepsilon$ model $^{52}$. In the case of braided rivers, a laboratory experiment demonstrated that the average geometry of a thread conformed to the near-threshold model, despite the braided threads' high mobility and tendency to ceaselessly remold the channels ${ }^{117}$. Similarly, field observations of a braided river found that the individual threads were, on average, each near-threshold channels ${ }^{118}$. These examples illustrate the concept that the $1+\varepsilon$ model can describe the average geometry of alluvial rivers, but says nothing about higher-order dynamics and their contributions to variations about the mean.

It is well known that increasing the entrainment threshold of bank materials - whether by vegetation or cohesion - can result in relatively narrower and deeper channels ${ }^{169}$, and affect a transition from braided to single-thread (meandering or straight) morphology ${ }^{170-172}$. This transition is predominantly controlled by channel aspect ratio ${ }^{51,53}$, through its influence on 
lateral flow instability ${ }^{116,173}$. The threshold-limited channel model explains how and why average channel geometry changes with bank material strength. The predicted geometry from the $1+\varepsilon$ model can be evaluated using a classical hydrodynamic stability criterion ${ }^{116}$, to predict whether one or multiple threads are expected. This approach has been shown to successfully describe the planform pattern of natural rivers ${ }^{53,54,118}$, and therefore may be useful for channel restoration schemes or predicting potential channel responses to changes in boundary conditions. The near-threshold model could also help to better constrain paleo-hydraulic conditions and channel pattern changes observed in past river deposits, on Earth ${ }^{174-176}$ and other planets such as Mars ${ }^{177-180 .}$

\section{Outstanding problems and opportunities}

\section{Hydroclimate change and timescales of river adjustment}

A fundamental question arises when considering the applicability of stationary models for hydraulic geometry: how, and how fast, do channels adjust their shape to changes in hydrology? This question is germane to determination of the requisite averaging timescale, as discussed above; it is also central to predicting channel response to climate and land-use changes. Each river may have its own adjustment timescales and patterns, determined by site-specific characteristics such as catchment morphology, geology and tectonics, hydroclimate, vegetation, land use and engineering conditions ${ }^{25,41,109,158,181}$. Due to these complexities, the question of channel adjustment must first be addressed empirically. In recent decades, the same USGS gage data discussed above has begun to be utilized to examine changes in cross-sectional geometry and hydraulic conveyance (fig. $5 a-c)^{107,182,183}$. Although not intended for this purpose, long-term gage records — extending decades and, in some cases, over a century — are the best available data for relating channel size to hydroclimate ${ }^{184,185}$.

A general observation is that, to first order, the hydraulic geometry of alluvial rivers is more-or-less adjusted to modern hydroclimate regimes. This can be inferred from the tight scaling relations between bankfull channel width, depth and discharge (Fig. 1e), and the general success of the stationary $1+\varepsilon$ model - which involves averaging timescales on the order of a decade or longer ${ }^{6}$. This result implies that statistically significant changes in hydroclimate - i.e., the frequency and magnitude of discharge events - may be expected to result in detectable changes in hydraulic geometry (Fig. 5 a-d). Indeed, multi-decadal trends in river channel form are widespread ${ }^{108}$. An analysis of almost a thousand, minimally-disturbed USGS gauges across the USA found that $2 / 3$ of the stations displayed significant temporal trends in riverbed elevation (Fig. 5), with disproportionately higher rates of change in drier regions ${ }^{107}$. Results imply that at least some of these trends may be attributable to anthropogenic-driven climate change, although no formal attribution analysis has yet been performed.

The sensitivity of alluvial river geometry to climate change is only just beginning to be explored. Hydroclimatic variability is typically expressed through the presence of "flood rich" and "flood poor" periods ${ }^{186}$. Large-scale modes of variability, such as the El Nino Southern Oscillation or the Atlantic Multidecadal Oscillation, alter precipitation and temperature patterns both regionally and globally, over different timescales ${ }^{187-189}$. Of particular importance for flooding is the change in precipitation and discharge forcing scenarios and the resulting channel response ${ }^{109}$ (Fig. 5 e-f). Anthropogenic-driven climate change is currently driving increases in the most intense precipitation events in many regions ${ }^{190,191}$. Analysis of long-term USGS gage data suggests that alluvial rivers may "breathe" with climate cycles; i.e., increase and decrease their conveyance capacity with flood rich and flood poor periods (fig. 5c), respectively ${ }^{109}$. Understanding the nature and pervasiveness of these changes is a burgeoning frontier research area for understanding the links between river geometry and hydroclimate. While some 
channel adjustment may result principally from changes in the frequency and intensity of sediment transport ${ }^{192}$ and therefore be amenable to a mechanics based solution, other factors may also contribute. For example, interannual vegetation growth — along channel banks, on bars, and within the upstream catchment - could contribute significantly both in changing the entrainment threshold, and also by potentially introducing lags and hysteresis in channel response ${ }^{193,194}$.

The considerations above offer some reassurance regarding the utility of the first-order $1+\varepsilon$ model for interpreting observed changes in mean hydraulic geometry as a consequence of climate change. They also, however, underscore a major shortcoming: the assumptions of stationary water and weather regimes are broken ${ }^{195}$ and many channels may be adjusting to a changing climate, climatic oscillations, significant shifts in land use, and/or water management (Fig. 5). The close agreement between channel width and discharge (Fig. 1e) indicates that the $1+\varepsilon$ model can be used to predict channel size following adjustment, however the rates and modes of adjustment cannot be predicted from a stationary model. To move forward with an empirical approach, the next logical step is to consider the information contained in the higher-order moments of channel geometry data. In other words, one possibility may be to consider river morphology and hydroclimate as probability density functions that evolve together over time. What would such an approach look like? The cross-sectional river width, for example, can be described as a probability density function ${ }^{168}$ that is reflective of such factors as formative discharge and sediment input, variations in threshold along the investigated reach, and additional mechanisms such as slump-block protection. In turn, river discharge can be described as a probability distribution that changes on annual or decadal timescales due to natural climate oscillations, human-induced climate change, water management, or land-use changes. Examination of the joint probability distributions of channel geometry and hydroclimate through time would open the door to statistical modeling of the influence of climate on alluvial rivers.

\section{Land use change and multiple stable states}

The $1+\varepsilon$ model provides a framework for anticipating how alluvial channels may adjust to changes in hydrology or land use, through their influence on factors such as the distributions of discharge and sediment flux. While channel adjustment may be complex and involve time lags, we have implicitly assumed that there is a unique, stationary average channel geometry for a fixed set of boundary conditions. We now consider the possibility, however, that there may exist multiple stable states of channel geometry under the same imposed boundary conditions, as a result of landscape history. The pioneering work of Walter and Merritts ${ }^{25}$ revealed the deep and lasting influence of legacy sediments, from centuries old land-use changes, on modern channel geometry and morphology. Most relevant here is their discovery that many small rivers in Northeastern USA used to be shallow, marshy, multi-channel systems before land clearing and mill dam construction (1600-early $\left.1900 \mathrm{~s}^{25}\right)$ induced the rapid filling of these valleys with fine sediments. Over centuries, however, much of these watersheds have reforested while abandoned dams have breached. Modern channels formed by slicing through these fine sediments, and the underlying pre-European colonization marsh muds, until they tapped a substrate of Pleistocene colluvium — cobbles with relatively high entrainment stresses that line the valley bottoms (Fig. 6). Although the strong perturbations to hydrology and sediment supply associated with mill production have been removed, the rivers have not returned to their original form. Rather, they are relatively deep and narrow, meandering channels ${ }^{25,196}$ that appear to be pattern stable (Fig. 6a-c). We posit that both channel states, pre-European colonization and modern, can be understood with the threshold-limited channel model. In this view, the shallow channels of the pre-European colonization (Holocene) era were adjusted to the entrainment threshold of the (vegetated) wetland muds and 
sands that lined their banks and beds ${ }^{25}$. Following dam failure and breaching that caused transient and focused erosion through loose legacy-sediment fill ${ }^{197}$ and Holocene marsh sediments, these channels adjusted to a new threshold-limiting material — the exhumed Pleistocene cobbles (Fig. 6d). Application of the threshold-limited model provides close predictions of the modern channel width (Fig. 6d). This case study reveals how the history of a landscape, embedded in sedimentary deposits, becomes a substrate that can exert a first-order control on channel geometry through the entrainment threshold. This idea has practical consequences: currently, major restoration projects are underway in some of these Northeastern rivers, based on the premise that channel geometry may be returned to pre-disturbance conditions by altering the substrate. More broadly, dam removal projects are rapidly growing in number around the world, with the similar goal of returning rivers to a natural state $^{198-201}$. The ultimate success of these projects will also be a measure of the success of the threshold-limited channel model.

\section{Understanding and predicting threshold}

If the $1+\varepsilon$ model is at least a sturdy vessel for encapsulating our current understanding of first-order channel patterns, it is anchored to a shifting bottom: the entrainment threshold. For all intents and purposes, $\tau_{c}$ of $i n$-situ river sediments — whether gravel beds, or cohesive river banks — cannot be predicted from existing models to better than a factor of ten ${ }^{52,125,152}$. Given our premise that alluvial rivers organize to near-threshold conditions, this suggests that the primary challenge in predicting channel geometry lies in proper determination of threshold itself. Extensive research on gravel-bed rivers has demonstrated the importance of myriad factors that make prediction so difficult: variability in grain protrusion and exposure ${ }^{129,202-204}$; granular structure effects including interlocking, armoring and compaction ${ }^{128,153,205,206}$; spatial segregation or patchiness in grain $\mathrm{size}^{93,207}$; and the sensitivity of the near-bed turbulent stress distribution to bed topography ${ }^{144,208-210}$. For cohesive bank-toe materials the situation is at least as challenging, as $\tau_{c}$ is sensitive to: variations in clay and organic content ${ }^{133,169}$; the degree of compaction $^{211}$; wetting and drying cycles ${ }^{212,213}$; and even water chemistry through its control on particle-surface charge ${ }^{141,142}$. The final challenge is that many of the aforementioned factors influencing threshold are spatially and temporally variable.

As a result of these challenges, we advocate that researchers and practitioners collect site-specific, in-situ measurements of $\tau_{c}$ for the most resistant material. There are currently so few measurements of cohesive bank-toe material that no general trends can be reported ${ }^{52}$; but our hope is that recent methodological improvements ${ }^{214}$ will allow for broader data collectiong. For gravel-bed rivers, a variety of techniques have been employed and reviewed elsewhere ${ }^{215}$; but impact plates ${ }^{216-218}$ and seismometers ${ }^{219-222}$ are emerging as tools for high-resolution temporal monitoring of bed-load transport and, by extension, the entrainment threshold. These tools have demonstrated that $\tau_{c}$ is moving target; its value appears to depend on the history of flows experienced by the river ${ }^{223}$. Observations of hysteresis in bed-load transport rate through individual floods have been used to infer that $\tau_{c}$ changes due to reorganization of the river bed ${ }^{223-225}$. Perhaps more intriguing is that $\tau_{c}$ appears to vary from flood to flood ${ }^{226}$, and to evolve through time even under sub-threshold conditions ${ }^{129,223}$. Recent laboratory experiments have begun to reveal the grain-scale origins of the temporal evolution of $\tau_{c}$. Low-intensity bed-load transport and sub-threshold creeping of grains both act to strain harden the bed and increase $\tau_{c}$, through compaction and reduction in the protrusion of grains at the surface ${ }^{129,153}$. Laboratory experiments with a unimodal grain size distribution demonstrate that high-intensity bed-load, however, appears to dilate sediment beds and destroy memory resulting in a decrease in $\tau_{c}{ }^{153}$.

It is beyond the scope of this paper to dive deeper into the origins of variation in $\tau_{c}$, but this behavior raises challenging questions for near-threshold rivers. Does channel geometry adjust to some time-averaged $\tau_{c}$ integrated over many flood 
events; or does channel adjustment require severe disruption of the bed structure, in which case the maximum $\tau_{c}$ may be more appropriate? Further, the linkage of $\tau_{c}$ with the frequency and magnitude of flood events suggests that potential changes in hydroclimate may alter the entrainment threshold itself — with knock-on consequences for channel geometry. The critical filter effect of channel geometry on bed-stress ${ }^{6}$, however, may limit the impact of high-magnitude floods on $\tau_{c}$. Moreover, the fact that $\tau_{c}$ may adjust over a range of values implies a certain buffering capacity; a river may absorb some changes in hydroclimate through reorganization of the river bed (and hence $\tau_{c}$ ), without changes in channel geometry. As earlier, here we suggest that adopting a probabilistic description of $\tau_{c}$ is a sensible next step. From a practical perspective, future work must endeavor to determine how — and for how long — to measure $\tau_{c}$ in the field.

\section{Conclusion}

In his seminal paper ${ }^{50}$ introducing the original $1+\varepsilon$ model, Gary Parker concluded: "Natural rivers are extremely complicated phenomena and it would be facile to assume that the present analysis provides a complete and accurate picture...Regime relations apply only to straight reaches with bed and banks composed of similar non-cohesive coarse gravel at bankfull." And yet, decades of subsequent data have shown that the regime relations indeed apply to complex natural rivers that flagrantly violate model assumptions. We have attempted to demonstrate, through appropriate parameterization and averaging, how and why this 'facile' model also explains the mean state of alluvial river geometry. In doing so, our hope is that this Review also serves as a guide for the practitioner in the proper application of the model to natural and engineered settings. The rich tapestry of higher-order behaviors that make rivers dynamic — dunes, bars and meanders, collapsing banks, growth and erosion of vegetation, and floods - are essentially fluctuations about the mean state. By analogy, the $1+\varepsilon$ model describes the climate of alluvial rivers, but says nothing about the weather. It is reasonable to assume that the inclusion of these fluctuations will improve hydraulic geometry predictions. This Review concludes, however, that the foremost challenge is to determine the appropriate entrainment threshold. An explosion in field studies characterizing timescales of channel adjustment, and the emergence of probabilistic descriptions of river geometry and hydroclimate, promise the development of future statistical models that will relax assumptions of stationarity. Such models are needed to predict the responses of alluvial rivers to rapidly changing boundary conditions, such as climate and watershed management.

\section{References}

1. Furbish, D. J., Haff, P. K., Roseberry, J. C. \& Schmeeckle, M. W. A probabilistic description of the bed load sediment flux: 1. Theory. J. Geophys. Res. Earth Surf. 117, DOI: https://doi.org/10.1029/2012JF002352. (2012).

2. Ancey, C. Bedload transport: a walk between randomness and determinism. Part 1. The state of the art. J. Hydraul. Res. 58, 1-17, DOI: 10.1080/00221686.2019.1702594. (2020).

3. Wickert, A. D., Mitrovica, J. X., Williams, C. \& Anderson, R. S. Gradual demise of a thin southern Laurentide ice sheet recorded by Mississippi drainage. Nature 502, 668-671, DOI: 10.1038/nature12609. (2013).

4. Lyster, S. J., Whittaker, A. C., Allison, P. A., Lunt, D. J. \& Farnsworth, A. Predicting sediment discharges and erosion rates in deep time-examples from the late Cretaceous North American continent. Basin Res. 32, 1547-1573, DOI: 10.1111/bre.12442. (2020).

5. Paola, C., Heller, P. L. \& Angevine, C. L. The large-scale dynamics of grain-size variation in alluvial basins, 1: Theory. Basin Res. (1992).

6. Phillips, C. B. \& Jerolmack, D. J. Self-organization of river channels as a critical filter on climate signals. Science 352, 694-697, DOI: 10.1126/science.aad3348. (2016). 
7. Wickert, A. D. \& Schildgen, T. F. Long-profile evolution of transport-limited gravel-bed rivers. Earth Surf. Dyn. 7, 17-43, DOI: https://doi.org/10.5194/esurf-7-17-2019. (2019).

8. Romans, B. W., Castelltort, S., Covault, J. A., Fildani, A. \& Walsh, J. P. Environmental signal propagation in sedimentary systems across timescales. Earth-Science Rev. 153, 7-29, DOI: 10.1016/j.earscirev.2015.07.012. (2016).

9. Hajek, E. A. \& Straub, K. M. Autogenic Sedimentation in Clastic Stratigraphy. Annu. Rev. Earth Planet. Sci. 45, 681-709, DOI: 10.1146/annurev-earth-063016-015935. (2017).

10. Paola, C., Ganti, V., Mohrig, D., Runkel, A. C. \& Straub, K. M. Time Not Our Time: Physical Controls on the Preservation and Measurement of Geologic Time. Annu. Rev. Earth Planet. Sci. 46, 409-438, DOI: 10.1146/annurev-earth-082517-010129. (2018).

11. McMillan, M. E., Heller, P. L. \& Wing, S. L. History and causes of post-Laramide relief in the Rocky Mountain orogenic plateau. GSA Bull. 118, 393-405, DOI: 10.1130/B25712.1. (2006).

12. Gomez-Velez, J. D., Harvey, J. W., Cardenas, M. B. \& Kiel, B. Denitrification in the Mississippi River network controlled by flow through river bedforms. Nat. Geosci. 8, 941-945, DOI: 10.1038/ngeo2567. (2015).

13. Allen, G. H. \& Pavelsky, T. M. Global extent of rivers and streams. Science 361, 585-588, DOI: 10.1126/science.aat0636. (2018).

14. Raymond, P. A. et al. Global carbon dioxide emissions from inland waters. Nature 503, 355-359, DOI: 10.1038/ nature12760. (2013).

15. Balian, E. V., Segers, H., Martens, K. \& Lévéque, C. The Freshwater Animal Diversity Assessment: an overview of the results. In Balian, E. V., Lévêque, C., Segers, H. \& Martens, K. (eds.) Freshwater Animal Diversity Assessment, Developments in Hydrobiology, 627-637, DOI: 10.1007/978-1-4020-8259-7_61 (Springer Netherlands, Dordrecht, 2007)

16. Doyle, M. The Source, How Rivers Made America and America Remade Its Rivers (W. W. Norton, New York, 2018).

17. Macklin, M. G. \& Lewin, J. The rivers of civilization. Quat. Sci. Rev. 114, 228-244, DOI: 10.1016/j.quascirev.2015.02.004. (2015).

18. Programme), W. W. W. A. The United Nations World Water Development Report 4 Volume 2: Managing Water under Uncertainty and Risk. Tech. Rep. 4, UNESCO, Paris

19. Vörösmarty, C. J. et al. Global threats to human water security and river biodiversity. Nature 467, 555-561, DOI: 10.1038/nature09440. (2010).

20. Tanoue, M., Hirabayashi, Y. \& Ikeuchi, H. Global-scale river flood vulnerability in the last 50 years. Sci. Reports 6 , 36021, DOI: 10.1038/srep36021. (2016).

21. Best, J. Anthropogenic stresses on the world's big rivers. Nat. Geosci. 12, 7-21, DOI: 10.1038/s41561-018-0262-x. (2019).

22. Opperman, J., Grill, G. \& Hartmann, J. The Power of Rivers: Finding balance between energy and conservation in hydropower development. Tech. Rep., The Nature Conservancy, Washington, DC

23. Latrubesse, E. M. et al. Damming the rivers of the Amazon basin. Nature 546, 363-369, DOI: 10.1038/nature22333. (2017).

24. Syvitski, J. P. M., Vörösmarty, C. J., Kettner, A. J. \& Green, P. Impact of Humans on the Flux of Terrestrial Sediment to the Global Coastal Ocean. Science 308, 376-380, DOI: 10.1126/science.1109454. (2005).

25. Walter, R. C. \& Merritts, D. J. Natural Streams and the Legacy of Water-Powered Mills. Science 319, 299-304, DOI: 10.1126/science.1151716. (2008).

26. Palmer, M. A. et al. Standards for ecologically successful river restoration. J. Appl. Ecol. 42, 208-217, DOI: https: //doi.org/10.1111/j.1365-2664.2005.01004.x. (2005).

27. Wohl, E., Lane, S. N. \& Wilcox, A. C. The science and practice of river restoration. Water Resour. Res. 51, 5974-5997, DOI: https://doi.org/10.1002/2014WR016874. (2015).

28. Benson, E. S. Random river: Luna Leopold and the promise of chance in fluvial geomorphology. J. Hist. Geogr. 67, 14-23, DOI: 10.1016/j.jhg.2019.10.007. (2020).

29. Leopold, L. B. \& Maddock, T. The Hydraulic Geometry of Stream Channels and Some Physiographic Implications. U.S. Geol. Surv. Prof. Pap. 252, DOI: 10.3133/pp252. (1953). 
30. Wolman, M. G. \& Miller, J. P. Magnitude and Frequency of Forces in Geomorphic Processes. The J. Geol. (1960).

31. Leopold, L. B. \& Wolman, M. G. River Channel Patterns: Braided, Meandering, and Straight. Tech. Rep. PP - 282-B, United States Geological Survey

32. Leopold, L. B., Wolman, M. G. \& Miller, J. P. Fluvial Processes in Geomorphology (WH Freeman and Company, San Francisco, 1964).

33. Lacey, G. Stable channels in alluvium. In Minutes of the Proceedings of the Institution of Civil Engineers, vol. 229, 259-292 (1930)

34. Parker, G., Wilcock, P., Paola, C., Dietrich, W. \& Pitlick, J. Physical basis for quasi-universal relations describing bankfull hydraulic geometry of single-thread gravel bed rivers. J. Geophys. Res. Surf. 112, DOI: 10.1029/2006JF000549. (2007).

35. Moody, J. A. \& Troutman, B. M. Characterization of the spatial variability of channel morphology. Earth Surf. Process. Landforms 27, 1251-1266, DOI: https://doi.org/10.1002/esp.403. (2002).

36. Andrews, E. D. Bed-material entrainment and hydraulic geometry of gravel-bed rivers in Colorado. Geol. Soc. Am. Bull. 95, 371-378, DOI: 10.1130/0016-7606(1984)95<371:BEAHGO>2.0.CO;2. (1984).

37. Gleason, C. J. Hydraulic geometry of natural rivers: A review and future directions. Prog. Phys. Geogr. Earth Environ. 39, 337-360, DOI: 10.1177/0309133314567584. (2015).

38. Wilkerson, G. V. \& Parker, G. Physical Basis for Quasi-Universal Relationships Describing Bankfull Hydraulic Geometry of Sand-Bed Rivers. J. Hydraul. Eng. 137, 739-753, DOI: 10.1061/(ASCE)HY.1943-7900.0000352. (2011).

39. Wohl, E. Limits of downstream hydraulic geometry. Geology 32, 897-900, DOI: 10.1130/G20738.1. (2004).

40. Allmendinger, N. E., Pizzuto, J. E., Potter, N., Johnson, T. E. \& Hession, W. C. The influence of riparian vegetation on stream width, eastern Pennsylvania, USA. Geol. Soc. Am. Bull. 117, 229-243, DOI: 10.1130/B25447.1. (2005).

41. Anderson, R. J., Bledsoe, B. P. \& Hession, W. C. Width of Streams and Rivers in Response to Vegetation, Bank Material, and Other Factors. JAWRA J. Am. Water Resour. Assoc. 40, 1159-1172, DOI: 10.1111/j.1752-1688.2004.tb01576.x. (2004).

42. Faustini, J. M., Kaufmann, P. R. \& Herlihy, A. T. Downstream variation in bankfull width of wadeable streams across the conterminous United States. Geomorphology 108, 292-311, DOI: 10.1016/j.geomorph.2009.02.005. (2009).

43. Park, C. C. World-wide variations in hydraulic geometry exponents of stream channels: An analysis and some observations. J. Hydrol. 33, 133-146, DOI: 10.1016/0022-1694(77)90103-2. (1977).

44. Métivier, F. et al. Geometry of meandering and braided gravel-bed threads from the Bayanbulak Grassland, Tianshan, P. R. China. Earth Surf. Dyn. 4, 273-283, DOI: https://doi.org/10.5194/esurf-4-273-2016. (2016).

45. Chezy, A. Thesis on the velocity of the flow in a given ditch. Ph.D., Ecole des Ponts et Chaussees, (1775)

46. Glover, R. E. \& Florey, Q. L. Stable channel profiles. Tech. Rep., U.S. Bur. Reclamation, Denver, CO. USA

47. Chow, V. T. Open-Channel Hydraulics (McGraw-Hill, New York, 1959).

48. Henderson, F. M. Stability of Alluvial Channels. J. Hydraul. Div. (1961).

49. Diplas, P. \& Vigilar, G. Hydraulic Geometry of Threshold Channels. J. Hydraul. Eng. 118, 597-614, DOI: 10.1061/ (ASCE)0733-9429(1992)118:4(597). (1992).

50. Parker, G. Self-formed straight rivers with equilibrium banks and mobile bed Part 2 . The gravel river. J. Fluid Mech. (1978).

51. Abramian, A., Devauchelle, O. \& Lajeunesse, E. Laboratory rivers adjust their shape to sediment transport. Phys. Rev. E 102, 053101, DOI: 10.1103/PhysRevE.102.053101. (2020).

52. Dunne, K. B. J. \& Jerolmack, D. J. What sets river width? Sci. Adv. 6, eabc1505, DOI: 10.1126/sciadv.abc1505. (2020).

53. Métivier, F., Lajeunesse, E. \& Devauchelle, O. Laboratory rivers: Lacey's law, threshold theory, and channel stability. Earth Surf. Dyn. 5, 187 - 198, DOI: 10.5194/esurf-5-187-2017. (2017).

54. Dunne, K. B. J. \& Jerolmack, D. J. Evidence of, and a proposed explanation for, bimodal transport states in alluvial rivers. Earth Surf. Dyn. (2018).

55. Trampush, S. M., Huzurbazar, S. \& McElroy, B. Empirical assessment of theory for bankfull characteristics of alluvial channels. Water Resour. Res. 50, 9211-9220, DOI: 10.1002/2014WR015597. (2014). 
56. Li, C., Czapiga, M. J., Eke, E. C., Viparelli, E. \& Parker, G. Variable Shields number model for river bankfull geometry: bankfull shear velocity is viscosity-dependent but grain size-independent. J. Hydraul. Res. 0, 1-13, DOI: 10.1080/00221686.2014.939113. (2014).

57. Czapiga, M. J., McElroy, B. \& Parker, G. Bankfull Shields number versus slope and grain size. J. Hydraul. Res. 57, 760-769, DOI: 10.1080/00221686.2018.1534287. (2019).

58. Millar, R. G. \& Quick, M. C. Effect of Bank Stability on Geometry of Gravel Rivers. J. Hydraul. Eng. 119, 1343-1363, DOI: 10.1061/(ASCE)0733-9429(1993)119:12(1343). (1993).

59. Darby, S. E. \& Thorne, C. R. Effect of Bank Stability on Geometry of Gravel Rivers. J. Hydraul. Eng. 121, 382-385, DOI: 10.1061/(ASCE)0733-9429(1995)121:4(382). (1995).

60. Huang, H. Q. \& Nanson, G. C. The influence of bank strength on channel geometry: an integrated analysis of some observations. Earth Surf. Process. Landforms 23, 865-876, DOI: https://doi.org/10.1002/(SICI)1096-9837(199810)23: 10<865::AID-ESP903>3.0.CO;2-3. (1998).

61. Pfeiffer, A. M., Finnegan, N. J. \& Willenbring, J. K. Sediment supply controls equilibrium channel geometry in gravel rivers. Proc. Natl. Acad. Sci. 114, 3346-3351, DOI: 10.1073/pnas.1612907114. (2017).

62. MacKenzie, L. G. \& Eaton, B. C. Large grains matter: contrasting bed stability and morphodynamics during two nearly identical experiments. Earth Surf. Process. Landforms 42, 1287-1295, DOI: https://doi.org/10.1002/esp.4122. (2017).

63. Lanzoni, S., Luchi, R. \& Bolla Pittaluga, M. Modeling the morphodynamic equilibrium of an intermediate reach of the Po River (Italy). Adv. Water Resour. 81, 95-102, DOI: 10.1016/j.advwatres.2014.11.004. (2015).

64. Wolman, M. G. \& Gerson, R. Relative scales of time and effectiveness of climate in watershed geomorphology. Earth Surf. Process. 3, 189-208, DOI: 10.1002/esp.3290030207. (1978).

65. Yu, B. \& Wolman, M. G. Some dynamic aspects of river geometry. Water Resour. Res. 23, 501-509, DOI: 10.1029/ WR023i003p00501. (1987).

66. Phillips, C. B. \& Jerolmack, D. J. Bankfull Transport Capacity and the Threshold of Motion in Coarse-Grained Rivers. Water Resour. Res. 55, 11316-11330, DOI: 10.1029/2019WR025455. (2019).

67. Eaton, B. C., Church, M. \& Millar, R. G. Rational regime model of alluvial channel morphology and response. Earth Surf. Process. Landforms 29, 511-529, DOI: https://doi.org/10.1002/esp.1062. (2004).

68. Eaton, B. C. \& Church, M. Predicting downstream hydraulic geometry: A test of rational regime theory. J. Geophys. Res. Earth Surf. 112, DOI: https://doi.org/10.1029/2006JF000734. (2007).

69. Bonakdari, H. et al. A Novel Comprehensive Evaluation Method for Estimating the Bank Profile Shape and Dimensions of Stable Channels Using the Maximum Entropy Principle. Entropy 22, 1218, DOI: 10.3390/e22111218. (2020).

70. Huang, H. Q. \& Warner, R. F. The multivariate controls of hydraulic geometry: A causal investigation in terms of boundary shear distribution. Earth Surf. Process. Landforms 20, 115-130, DOI: https://doi.org/10.1002/esp.3290200203. (1995).

71. Nanson, G. C. \& Huang, H. Q. A philosophy of rivers: Equilibrium states, channel evolution, teleomatic change and least action principle. Geomorphology 302, 3-19, DOI: 10.1016/j.geomorph.2016.07.024. (2018).

72. Francalanci, S., Lanzoni, S., Solari, L. \& Papanicolaou, A. N. Equilibrium Cross Section of River Channels With Cohesive Erodible Banks. J. Geophys. Res. Earth Surf. 125, DOI: 10.1029/2019JF005286. (2020).

73. Xu, F. et al. A Universal Form of Power Law Relationships for River and Stream Channels. Geophys. Res. Lett. 47, e2020GL090493, DOI: https://doi.org/10.1029/2020GL090493. (2020).

74. Pelletier, J. D. Controls on the hydraulic geometry of alluvial channels: bank stability to gravitational failure, the criticalflow hypothesis, and conservation of mass and energy. Earth Surf. Dyn. Discuss. 1-18, DOI: 10.5194/esurf-2020-44. (2020).

75. Deltares. Delft3D-FLOW User Manual: Simulation of Multi-Dimensional Hydrodynamic Flows and Transport Phenomena, Including Sediments. Tech. Rep., Deltares, Delft, The Netherlands

76. Schuurman, F., Marra, W. A. \& Kleinhans, M. G. Physics-based modeling of large braided sand-bed rivers: Bar pattern formation, dynamics, and sensitivity. J. Geophys. Res. Earth Surf. 118, 2509-2527, DOI: https://doi.org/10.1002/ 2013JF002896. (2013).

77. Church, M. \& Ferguson, R. I. Morphodynamics: Rivers beyond steady state. Water Resour. Res. 51, 1883-1897, DOI: https://doi.org/10.1002/2014WR016862. (2015). 
78. Garcia, M. Sedimentation Engineering: Processes, Measurements, Modeling, and Practice, vol. Sedimentation Engineering of ASCE MOP (ASCE, 2008).

79. Church, M. Bed Material Transport and the Morphology of Alluvial River Channels. Annu. Rev. Earth Planet. Sci. 34, 325-354, DOI: 10.1146/annurev.earth.33.092203.122721. (2006).

80. Bednarek, A. T. Undamming Rivers: A Review of the Ecological Impacts of Dam Removal. Environ. Manag. 27, 803-814, DOI: 10.1007/s002670010189. (2001).

81. Wilcock, P. R. Stream Restoration in Gravel-Bed Rivers. In Gravel-Bed Rivers, 135-149, DOI: 10.1002/9781119952497. ch12 (John Wiley \& Sons, Ltd, 2012)

82. Sklar, L. S. \& Dietrich, W. E. A mechanistic model for river incision into bedrock by saltating bed load: bedrock incision by saltating bedload. Water Resour. Res. 40, DOI: 10.1029/2003WR002496. (2004).

83. Chatanantavet, P. \& Parker, G. Physically based modeling of bedrock incision by abrasion, plucking, and macroabrasion. J. Geophys. Res. 114, F04018, DOI: 10.1029/2008JF001044. (2009).

84. Finnegan, N. J., Roe, G., Montgomery, D. R. \& Hallet, B. Controls on the channel width of rivers: Implications for modeling fluvial incision of bedrock. Geology 33, 229-232, DOI: 10.1130/G21171.1. (2005).

85. Johnson, J. P. L. \& Whipple, K. X. Evaluating the controls of shear stress, sediment supply, alluvial cover, and channel morphology on experimental bedrock incision rate. J. Geophys. Res. Surf. 115, DOI: 10.1029/2009JF001335. (2010).

86. Wohl, E. \& David, G. C. L. Consistency of scaling relations among bedrock and alluvial channels. J. Geophys. Res. Earth Surf. 113, F04013, DOI: 10.1029/2008JF000989. (2008).

87. Turowski, J. M., Hovius, N., Wilson, A. \& Horng, M.-J. Hydraulic geometry, river sediment and the definition of bedrock channels. Geomorphology 99, 26-38, DOI: 10.1016/j.geomorph.2007.10.001. (2008).

88. Whipple, K. X. Bedrock Rivers and the Geomorphology of Active Orogens. Annu. Rev. Earth Planet. Sci. 32, 151-185, DOI: 10.1146/annurev.earth.32.101802.120356. (2004).

89. Izumi, N. \& Parker, G. Linear stability analysis of channel inception: downstream-driven theory. J. Fluid Mech. 419, 239-262, DOI: 10.1017/S0022112000001427. (2000).

90. Schorghofer, N., Jensen, B., Kudrolli, A. \& Rothman, D. H. Spontaneous channelization in permeable ground: theory, experiment, and observation. J. Fluid Mech. 503, 357-374, DOI: 10.1017/S0022112004007931. (2004).

91. Abramian, A., Devauchelle, O. \& Lajeunesse, E. Streamwise streaks induced by bedload diffusion. J. Fluid Mech. 863, 601-619, DOI: 10.1017/jfm.2018.1024. (2019).

92. Nikora, V. \& Roy, A. G. Secondary Flows in Rivers: Theoretical Framework, Recent Advances, and Current Challenges. In Gravel-Bed Rivers, 1-22, DOI: 10.1002/9781119952497.ch1 (John Wiley \& Sons, Ltd, 2012)

93. Paola, C. \& Seal, R. Grain-Size Patchiness as a Cause of Selective Deposition and Downstream Fining. Water Resour. Res. 31, 1395-1407, DOI: 10.1029/94WR02975. (1995).

94. Coulthard, T. J. \& Van De Wiel, M. J. Modelling river history and evolution. Philos. Transactions Royal Soc. A: Math. Phys. Eng. Sci. 370, 2123-2142, DOI: 10.1098/rsta.2011.0597. (2012).

95. Seminara, G. Meanders. J. Fluid Mech. 554, 271-297, DOI: 10.1017/S0022112006008925. (2006).

96. Zolezzi, G. \& Seminara, G. Downstream and upstream influence in river meandering. Part 2. Planimetric development. $J$. Fluid Mech. 438, 183-211, DOI: 10.1017/S002211200100427X. (2001).

97. Bogoni, M., Putti, M. \& Lanzoni, S. Modeling meander morphodynamics over self-formed heterogeneous floodplains. Water Resour. Res. 53, 5137-5157, DOI: https://doi.org/10.1002/2017WR020726. (2017).

98. Frascati, A. \& Lanzoni, S. A mathematical model for meandering rivers with varying width. J. Geophys. Res. Earth Surf. 118, 1641-1657, DOI: https://doi.org/10.1002/jgrf.20084. (2013).

99. Olsen, N. R. B. Three-Dimensional CFD Modeling of Self-Forming Meandering Channel. J. Hydraul. Eng. 129, 366-372, DOI: 10.1061/(ASCE)0733-9429(2003)129:5(366). (2003).

100. Schmeeckle, M. W. Numerical simulation of turbulence and sediment transport of medium sand. J. Geophys. Res. Earth Surf. 119, 1240-1262, DOI: https://doi.org/10.1002/2013JF002911. (2014).

101. Wolman, M. G. A method of sampling coarse river-bed material. Transactions, Am. Geophys. Union (1954).

102. Williams, G. P. Bank-full discharge of rivers. Water Resour. Res. 14, 1141-1154, DOI: 10.1029/WR014i006p01141. (1978). 
103. Lindroth, E. M. et al. Spatial Variability in Bankfull Stage and Bank Elevations of Lowland Meandering Rivers: Relation to Rating Curves and Channel Planform Characteristics. Water Resour. Res. 56, e2020WR027477, DOI: https://doi.org/10.1029/2020WR027477. (2020).

104. Sauer, V. B. \& Turnipseed, D. P. Stage measurement at gaging stations. USGS Numbered Series 3-A7, U.S. Geological Survey, Reston, VA (2010).

105. Turnipseed, D. P. \& Sauer, V. B. Discharge measurements at gaging stations. USGS Numbered Series 3-A8, U.S. Geological Survey, Reston, VA (2010).

106. Hodgkins, G. A., Norris, J. M. \& Lent, R. M. The USGS National Streamflow Information Program and the importance of preserving long-term streamgages. USGS Numbered Series 2014-3026, U.S. Geological Survey, Reston, VA (2014).

107. Slater, L. J. \& Singer, M. B. Imprint of climate and climate change in alluvial riverbeds: Continental United States, 1950-2011. Geology 41, 595-598, DOI: 10.1130/G34070.1. (2013).

108. Slater, L. J., Singer, M. B. \& Kirchner, J. W. Hydrologic versus geomorphic drivers of trends in flood hazard. Geophys. Res. Lett. 42, 370-376, DOI: 10.1002/2014GL062482. (2015).

109. Slater, L. J., Khouakhi, A. \& Wilby, R. L. River channel conveyance capacity adjusts to modes of climate variability. Sci. Reports 9, 1-10, DOI: 10.1038/s41598-019-48782-1. (2019).

110. Phillips, C. B. Alluvial River Bankfull Downstream Hydraulic Geometry. Hydroshare (2021). URL http://www. hydroshare.org/resource/fa5503b04af343ffbaf33d5a15cb2579.

111. Parker, G. et al. Alluvial fans formed by channelized fluvial and sheet flow. II: Application. J. Hydraul. Eng. (1998).

112. Parker, G. ID sediment transport morphodynamics with applications to rivers and turbidity currents, vol. 13 (E-Book, Urbana Champaign, Illinois, 2004).

113. Zhou, Z. et al. Is "Morphodynamic Equilibrium" an oxymoron? Earth-Science Rev. 165, 257-267, DOI: 10.1016/j. earscirev.2016.12.002. (2017).

114. Seizilles, G., Devauchelle, O., Lajeunesse, E. \& Métivier, F. Width of laminar laboratory rivers. Phys. Rev. E 87, 052204, DOI: 10.1103/PhysRevE.87.052204. (2013).

115. Stebbings, J. The shapes of self-formed model alluvial channels. Proc. Inst. Civ. Eng. 25, 485-510, DOI: 10.1680/iicep. 1963.10544. (1963).

116. Parker, G. On the cause and characteristic scales of meandering and braiding in rivers. J. Fluid Mech. 76, 457-480, DOI: 10.1017/S0022112076000748. (1976).

117. Reitz, M. D. et al. Diffusive evolution of experimental braided rivers. Phys. Rev. E 89, 052809, DOI: 10.1103/PhysRevE. 89.052809. (2014).

118. Gaurav, K. et al. Morphology of the Kosi megafan channels. Earth Surf. Dyn. 3, 321-331, DOI: 10.5194/esurf-3-321-2015. (2015).

119. Jaeger, H. M., Nagel, S. R. \& Behringer, R. P. Granular solids, liquids, and gases. Rev. Mod. Phys. 68, 1259-1273, DOI: 10.1103/RevModPhys.68.1259. (1996).

120. Shields, A. Application of similarity principles and turbulence research to bed-load movement. Ph.D., (1936)

121. Wiberg, P. L. \& Smith, J. D. Calculations of the Critical Shear Stress for Motion of Uniform and Heterogeneous Sediments. Water Resour. Res. 23, 1471-1480, DOI: 10.1029/WR023i008p01471. (1987).

122. Lamb, M. P., Brun, F. \& Fuller, B. M. Direct measurements of lift and drag on shallowly submerged cobbles in steep streams: Implications for flow resistance and sediment transport. Water Resour. Res. 53, 7607-7629, DOI: 10.1002/2017WR020883. (2017).

123. Lamb, M. P., Brun, F. \& Fuller, B. M. Hydrodynamics of steep streams with planar coarse-grained beds: Turbulence, flow resistance, and implications for sediment transport. Water Resour. Res. 53, 2240-2263, DOI: 10.1002/2016WR019579. (2017).

124. Seminara, G., Solari, L. \& Parker, G. Bed load at low Shields stress on arbitrarily sloping beds: Failure of the Bagnold hypothesis. Water Resour. Res. 38, 31-1-31-16, DOI: 10.1029/2001WR000681. (2002).

125. Lamb, M. P., Dietrich, W. E. \& Venditti, J. G. Is the critical Shields stress for incipient sediment motion dependent on channel-bed slope? J. Geophys. Res. 113, F02008, DOI: 10.1029/2007JF000831. (2008). 
126. Prancevic, J. P. \& Lamb, M. P. Unraveling bed slope from relative roughness in initial sediment motion. J. Geophys. Res. Earth Surf. 120, 2014JF003323, DOI: 10.1002/2014JF003323. (2015).

127. Recking, A. Theoretical development on the effects of changing flow hydraulics on incipient bed load motion. Water Resour. Res. 45, W04401, DOI: 10.1029/2008WR006826. (2009).

128. Church, M., Hassan, M. A. \& Wolcott, J. F. Stabilizing self-organized structures in gravel-bed stream channels: Field and experimental observations. Water Resour. Res. 34, 3169-3179, DOI: 10.1029/98WR00484. (1998).

129. Masteller, C. C. \& Finnegan, N. J. Interplay between grain protrusion and sediment entrainment in an experimental flume. J. Geophys. Res. Earth Surf. 122, 2016JF003943, DOI: 10.1002/2016JF003943. (2017).

130. Wilcock, P. R. Two-Fraction Model of Initial Sediment Motion in Gravel-Bed Rivers. Science 280, 410-412, DOI: 10.1126/science.280.5362.410. (1998).

131. Wilcock, P. R. \& Crowe, J. C. Surface-based Transport Model for Mixed-Size Sediment. J. Hydraul. Eng. (2003).

132. Kothyari, U. C. \& Jain, R. K. Influence of cohesion on the incipient motion condition of sediment mixtures. Water Resour. Res. 44, W04410, DOI: 10.1029/2007WR006326. (2008).

133. Aberle, J., Nikora, V. \& Walters, R. Effects of bed material properties on cohesive sediment erosion. Mar. Geol. 207, 83-93, DOI: 10.1016/j.margeo.2004.03.012. (2004).

134. Grabowski, R. C., Droppo, I. G. \& Wharton, G. Erodibility of cohesive sediment: The importance of sediment properties. Earth-Science Rev. 105, 101-120, DOI: 10.1016/j.earscirev.2011.01.008. (2011).

135. Zhang, M. \& Yu, G. Critical conditions of incipient motion of cohesive sediments. Water Resour. Res. 53, 7798-7815, DOI: https://doi.org/10.1002/2017WR021066. (2017).

136. Dallmann, J. et al. Impacts of suspended clay particle deposition on sand-bed morphodynamics. Water Resour. Res. e2019WR027010, DOI: 10.1029/2019WR027010. (2020).

137. Parsons, D. R. et al. The role of biophysical cohesion on subaqueous bed form size. Geophys. Res. Lett. 43, 1566-1573, DOI: https://doi.org/10.1002/2016GL067667. (2016).

138. Julian, J. P. \& Torres, R. Hydraulic erosion of cohesive riverbanks. Geomorphology 76, 193-206, DOI: 10.1016/j. geomorph.2005.11.003. (2006).

139. Baas, J. H., Davies, A. G. \& Malarkey, J. Bedform development in mixed sand-mud: The contrasting role of cohesive forces in flow and bed. Geomorphology 182, 19-32, DOI: 10.1016/j.geomorph.2012.10.025. (2013).

140. Malarkey, J. et al. The pervasive role of biological cohesion in bedform development. Nat. Commun. 6, 6257, DOI: 10.1038/ncomms7257. (2015).

141. Akinola, A. I., Wynn-Thompson, T., Olgun, C. G., Mostaghimi, S. \& Eick, M. J. Fluvial Erosion Rate of Cohesive Streambanks Is Directly Related to the Difference in Soil and Water Temperatures. J. Environ. Qual. 48, 1741-1748, DOI: https://doi.org/10.2134/jeq2018.10.0385. (2019).

142. Hoomehr, S., Akinola, A. I., Wynn-Thompson, T., Garnand, W. \& Eick, M. J. Water Temperature, pH, and Road Salt Impacts on the Fluvial Erosion of Cohesive Streambanks. Water 10, 302, DOI: 10.3390/w10030302. (2018).

143. Kean, J. W. \& Smith, J. D. Form drag in rivers due to small-scale natural topographic features: 1 . Regular sequences. $J$. Geophys. Res. Earth Surf. 111, DOI: https://doi.org/10.1029/2006JF000467. (2006).

144. Nikora, V., Goring, D., McEwan, I. \& Griffiths, G. Spatially Averaged Open-Channel Flow over Rough Bed. J. Hydraul. Eng. 127, 123-133, DOI: 10.1061/(ASCE)0733-9429(2001)127:2(123). (2001).

145. Feynman, R. P., Leighton, R. B. \& Sands, M. The Feynman lectures on physics, Vol. I: The new millennium edition: mainly mechanics, radiation, and heat, vol. 1 (Basic books, 2011).

146. Cassel, K. W. Variational methods with applications in science and engineering (Cambridge University Press, 2013).

147. Hanc, J. \& Taylor, E. F. From conservation of energy to the principle of least action: A story line. Am. J. Phys. (2004).

148. Kirkby, M. J. Maximum sediment efficiency as a criterion for alluvial channels. In Gregory, K. J. (ed.) River channel changes, 429-442 (Wiley Interscience, New York, 1977)

149. Huang, H. Q. \& Nanson, G. C. Hydraulic geometry and maximum flow efficiency as products of the principle of least action. Earth Surf. Process. Landforms 25, 1-16, DOI: https://doi.org/10.1002/(SICI)1096-9837(200001)25:1<1:: AID-ESP68>3.0.CO;2-2. (2000).

150. Santambrogio, F. Optimal transport for applied mathematicians. Birkauser, $N Y$ (2015). 
151. Birnir, B. \& Rowlett, J. Mathematical Models for Erosion and the Optimal Transportation of Sediment. Int. J. Nonlinear Sci. Numer. Simul. 14, DOI: 10.1515/ijnsns-2013-0048. (2013).

152. Buffington, J. M. \& Montgomery, D. R. A systematic analysis of eight decades of incipient motion studies, with special reference to gravel-bedded rivers. Water Resour. Res. 33, PP. 1993-2029, DOI: 199710.1029/96WR03190. (1997).

153. Houssais, M., Ortiz, C. P., Durian, D. J. \& Jerolmack, D. J. Onset of sediment transport is a continuous transition driven by fluid shear and granular creep. Nat. Commun. 6, 6527, DOI: 10.1038/ncomms7527. (2015).

154. Mueller, E. R., Pitlick, J. \& Nelson, J. M. Variation in the reference Shields stress for bed load transport in gravel-bed streams and rivers. Water Resour. Res. 41, W04006, DOI: 10.1029/2004WR003692. (2005).

155. Wilcock, P. R. \& McArdell, B. W. Partial transport of a sand/gravel sediment. Water Resour. Res. 33, 235-245, DOI: 10.1029/96WR02672. (1997).

156. Rijn, V. \& C, L. Erodibility of Mud-Sand Bed Mixtures. J. Hydraul. Eng. 146, 04019050, DOI: 10.1061/(ASCE)HY. 1943-7900.0001677. (2020).

157. Blom, A., Arkesteijn, L., Chavarrías, V. \& Viparelli, E. The equilibrium alluvial river under variable flow and its channel-forming discharge. J. Geophys. Res. Earth Surf. 122, 1924-1948, DOI: https://doi.org/10.1002/2017JF004213. (2017).

158. Naito, K. \& Parker, G. Adjustment of self-formed bankfull channel geometry of meandering rivers: modelling study. Earth Surf. Process. Landforms 45, 3313-3322, DOI: https://doi.org/10.1002/esp.4966. (2020).

159. Pitlick, J., Marr, J. \& Pizzuto, J. Width adjustment in experimental gravel-bed channels in response to overbank flows. $J$. Geophys. Res. Surf. 118, 553-570, DOI: 10.1002/jgrf.20059. (2013).

160. Andrews, E. D. Effective and bankfull discharges of streams in the Yampa River basin, Colorado and Wyoming. J. Hydrol. 46, 311-330, DOI: 10.1016/0022-1694(80)90084-0. (1980).

161. Emmett, W. W. \& Wolman, M. G. Effective discharge and gravel-bed rivers. Earth Surf. Process. Landforms 26, 1369-1380, DOI: https://doi.org/10.1002/esp.303. (2001).

162. Torizzo, M. \& Pitlick, J. Magnitude-frequency of bed load transport in mountain streams in Colorado. J. Hydrol. 290, 137-151, DOI: 10.1016/j.jhydrol.2003.12.001. (2004).

163. Barry, J. J., Buffington, J. M., Goodwin, P., King, J. G. \& Emmett, W. W. Performance of Bed-Load Transport Equations Relative to Geomorphic Significance: Predicting Effective Discharge and Its Transport Rate. J. Hydraul. Eng. 134, 601-615, DOI: 10.1061/(ASCE)0733-9429(2008)134:5(601). (2008).

164. Molnar, P., Anderson, R. S., Kier, G. \& Rose, J. Relationships among probability distributions of stream discharges in floods, climate, bed load transport, and river incision. J. Geophys. Res. Earth Surf. 111, DOI: 10.1029/2005JF000310. (2006).

165. Phillips, C. B., Martin, R. L. \& Jerolmack, D. J. Impulse framework for unsteady flows reveals superdiffusive bed load transport. Geophys. Res. Lett. 40, 1328-1333, DOI: 10.1002/grl.50323. (2013).

166. Pittaluga, M. B., Luchi, R. \& Seminara, G. On the equilibrium profile of river beds. J. Geophys. Res. Earth Surf. 119, 317-332, DOI: https://doi.org/10.1002/2013JF002806. (2014).

167. Mason, J. \& Mohrig, D. Differential bank migration and the maintenance of channel width in meandering river bends. Geology 47, 1136-1140, DOI: 10.1130/G46651.1. (2019).

168. Lopez Dubon, S. \& Lanzoni, S. Meandering Evolution and Width Variations: A Physics-Statistics-Based Modeling Approach. Water Resour. Res. 55, 76-94, DOI: 10.1029/2018WR023639. (2019).

169. Schumm, S. A. The shape of alluvial channels in relation to sediment type. Prof. Pap. DOI: 10.3133/pp352B. (1960).

170. Tal, M. \& Paola, C. Dynamic single-thread channels maintained by the interaction of flow and vegetation. Geology 35, 347-350, DOI: 10.1130/G23260A.1. (2007).

171. Braudrick, C. A., Dietrich, W. E., Leverich, G. T. \& Sklar, L. S. Experimental evidence for the conditions necessary to sustain meandering in coarse-bedded rivers. Proc. Natl. Acad. Sci. 106, 16936-16941, DOI: 10.1073/pnas.0909417106. (2009).

172. Dulal, K. P. \& Shimizu, Y. Experimental simulation of meandering in clay mixed sediments. J. Hydro-environment Res. 4, 329-343, DOI: 10.1016/j.jher.2010.05.001. (2010).

173. Seminara, G. Fluvial Sedimentary Patterns. Annu. Rev. Fluid Mech. 42, 43-66, DOI: 10.1146/ annurev-fluid-121108-145612. (2009). 
174. Davies, N. S. \& Gibling, M. R. Cambrian to Devonian evolution of alluvial systems: The sedimentological impact of the earliest land plants. Earth-Science Rev. 98, 171-200, DOI: 10.1016/j.earscirev.2009.11.002. (2010).

175. Ganti, V., Whittaker, A. C., Lamb, M. P. \& Fischer, W. W. Low-gradient, single-threaded rivers prior to greening of the continents. Proc. Natl. Acad. Sci. 116, 11652-11657, DOI: 10.1073/pnas.1901642116. (2019).

176. Ielpi, A. \& Lapôtre, M. G. A. A tenfold slowdown in river meander migration driven by plant life. Nat. Geosci. 13, 82-86, DOI: 10.1038/s41561-019-0491-7. (2020).

177. Jerolmack, D. J., Mohrig, D., Zuber, M. T. \& Byrne, S. A minimum time for the formation of Holden Northeast fan, Mars. Geophys. Res. Lett. 31, DOI: https://doi.org/10.1029/2004GL021326. (2004).

178. Williams, R. M. E. et al. Martian Fluvial Conglomerates at Gale Crater. Science 340, 1068-1072, DOI: 10.1126/science. 1237317. (2013).

179. Szabó, T., Domokos, G., Grotzinger, J. P. \& Jerolmack, D. J. Reconstructing the transport history of pebbles on Mars. Nat. Commun. 6, 8366, DOI: 10.1038/ncomms9366. (2015).

180. Kite, E. S. et al. Persistence of intense, climate-driven runoff late in Mars history. Sci. Adv. 5, eaav7710, DOI: 10.1126/sciadv.aav7710. (2019).

181. Call, B. C., Belmont, P., Schmidt, J. C. \& Wilcock, P. R. Changes in floodplain inundation under nonstationary hydrology for an adjustable, alluvial river channel. Water Resour. Res. 53, 3811-3834, DOI: https://doi.org/10.1002/2016WR020277. (2017).

182. James, L. A. Channel incision on the Lower American River, California, from streamflow gage records. Water Resour. Res. 33, 485-490, DOI: https://doi.org/10.1029/96WR03685. (1997).

183. Stover, S. C. \& Montgomery, D. R. Channel change and flooding, Skokomish River, Washington. J. Hydrol. 243, 272-286, DOI: 10.1016/S0022-1694(00)00421-2. (2001).

184. Smelser, M. G. \& Schmidt, J. C. An assessment methodology for determining historical changes in mountain streams. Gen. Tech. Rep. RMRS-GTR-6. Fort Collins, CO: U.S. Dep. Agric. For. Serv. Rocky Mountain Res. Station. 29 p. 6, DOI: 10.2737/RMRS-GTR-6. (1998).

185. Juracek, K. E. \& Fitzpatrick, F. A. Geomorphic applications of stream-gage information. River Res. Appl. 25, 329-347, DOI: https://doi.org/10.1002/rra.1163. (2009).

186. Blöschl, G. et al. Current european flood-rich period exceptional compared with past 500 years. Nature (2020).

187. Enfield, D. B., Mestas-Nuñez, A. M. \& Trimble, P. J. The Atlantic Multidecadal Oscillation and its relation to rainfall and river flows in the continental U.S. Geophys. Res. Lett. 28, 2077-2080, DOI: https://doi.org/10.1029/2000GL012745. (2001).

188. Liu, Z. et al. Pacific North American circulation pattern links external forcing and North American hydroclimatic change over the past millennium. Proc. Natl. Acad. Sci. 114, 3340-3345, DOI: 10.1073/pnas.1618201114. (2017).

189. Hodgkins, G. A. et al. Climate-driven variability in the occurrence of major floods across North America and Europe. $J$. Hydrol. 552, 704-717, DOI: 10.1016/j.jhydrol.2017.07.027. (2017).

190. Fowler, H. J. et al. Anthropogenic intensification of short-duration rainfall extremes. Nat. Rev. Earth \& Environ. 2, 107-122, DOI: 10.1038/s43017-020-00128-6. (2021).

191. Hayhoe, K. et al. Our Changing Climate. In Impacts, Risks, and Adaptation in the United States: Fourth National Climate Assessment. U.S. Glob. Chang. Res. Program, Washington, DC, USA 72-144, DOI: 10.7930/NCA4.2018.CH2. (2018).

192. Pfeiffer, A. M., Collins, B. D., Anderson, S. W., Montgomery, D. R. \& Istanbulluoglu, E. River bed elevation variability reflects sediment supply, rather than peak flows, in the uplands of washington state. Water Resour. Res. (2019).

193. Gurnell, A. M., Bertoldi, W. \& Corenblit, D. Changing river channels: The roles of hydrological processes, plants and pioneer fluvial landforms in humid temperate, mixed load, gravel bed rivers. Earth-Science Rev. 111, 129-141, DOI: 10.1016/j.earscirev.2011.11.005. (2012).

194. Walker, A. E., Moore, J. N., Grams, P. E., Dean, D. J. \& Schmidt, J. C. Channel narrowing by inset floodplain formation of the lower Green River in the Canyonlands region, Utah. GSA Bull. 132, 2333-2352, DOI: 10.1130/B35233.1. (2020).

195. Slater, L. J. et al. Nonstationary weather and water extremes: a review of methods for their detection, attribution, and management. Hydrol. Earth Syst. Sci. Discuss. (2020).

196. Merritts, D. et al. The rise and fall of Mid-Atlantic streams: Millpond sedimentation, milldam breaching, channel incision, and stream bank erosion. DOI: 10.1130/2013.4121(14). (2013). 
197. Merritts, D. et al. Anthropocene streams and base-level controls from historic dams in the unglaciated mid-Atlantic region, USA. Philos. Transactions Royal Soc. A: Math. Phys. Eng. Sci. 369, 976-1009, DOI: 10.1098/rsta.2010.0335. (2011).

198. Bernhardt, E. S. \& Palmer, M. A. River restoration: the fuzzy logic of repairing reaches to reverse catchment scale degradation. Ecol. Appl. 21, 1926-1931, DOI: https://doi.org/10.1890/10-1574.1. (2011).

199. Palmer, M. \& Ruhi, A. Linkages between flow regime, biota, and ecosystem processes: Implications for river restoration. Science 365, DOI: 10.1126/science.aaw2087. (2019).

200. East, A. E. et al. Geomorphic Evolution of a Gravel-Bed River Under Sediment-Starved Versus Sediment-Rich Conditions: River Response to the World's Largest Dam Removal. J. Geophys. Res. Earth Surf. 123, 3338-3369, DOI: https: //doi.org/10.1029/2018JF004703. (2018).

201. Bellmore, J. R. et al. Conceptualizing Ecological Responses to Dam Removal: If You Remove It, What's to Come? BioScience 69, 26-39, DOI: 10.1093/biosci/biy152. (2019).

202. Brayshaw, A. C. Bed microtopography and entrainment thresholds in gravel-bed rivers. GSA Bull. 96, 218-223, DOI: 10.1130/0016-7606(1985)96<218:BMAETI >2.0.CO;2. (1985).

203. Kirchner, J. W., Dietrich, W. E., Iseya, F. \& Ikeda, H. The variability of critical shear stress, friction angle, and grain protrusion in water worked sediments. Sedimentology (1990).

204. Yager, E. M., Schmeeckle, M. W. \& Badoux, A. Resistance Is Not Futile: Grain Resistance Controls on Observed Critical Shields Stress Variations. J. Geophys. Res. Earth Surf. 123, 3308-3322, DOI: 10.1029/2018JF004817. (2018).

205. Ferdowsi, B., Ortiz, C. P., Houssais, M. \& Jerolmack, D. J. River-bed armouring as a granular segregation phenomenon. Nat. Commun. 8, 1363, DOI: 10.1038/s41467-017-01681-3. (2017).

206. Ockelford, A., Yager, E. \& Idaho, U. The Initiation of Motion and Formation of Armour Layers. Treatise on Geomorphol. DOI: 10.1016/B978-0-12-818234-5.00005-5. (2020).

207. Nelson, P. A. et al. Response of bed surface patchiness to reductions in sediment supply. J. Geophys. Res. 114, 18 PP., DOI: 200910.1029/2008JF001144. (2009).

208. Recking, A. An analysis of nonlinearity effects on bed load transport prediction. J. Geophys. Res. Earth Surf. 118, 1264-1281, DOI: 10.1002/jgrf.20090. (2013).

209. Monsalve, A., Yager, E. M., Turowski, J. M. \& Rickenmann, D. A probabilistic formulation of bed load transport to include spatial variability of flow and surface grain size distributions. Water Resour. Res. 52, 3579-3598, DOI: 10.1002/2015WR017694. (2016).

210. Yager, E. M., Venditti, J. G., Smith, H. J. \& Schmeeckle, M. W. The trouble with shear stress. Geomorphology 323, 41-50, DOI: 10.1016/j.geomorph.2018.09.008. (2018).

211. Laflen, J. M. \& Beasley, R. P. Effects of compaction on critical tractive forces in cohesive soils. (1960).

212. Wolman, M. G. Factors Influencing Erosion of a Cohesive River Bank. Am. J. Sci. 257, 204-216, DOI: 10.2475/ajs.257.3. 204. (1959).

213. Wynn, T. M., Henderson, M. B. \& Vaughan, D. H. Changes in streambank erodibility and critical shear stress due to subaerial processes along a headwater stream, southwestern Virginia, USA. Geomorphology 97, 260-273, DOI: 10.1016/j.geomorph.2007.08.010. (2008).

214. Dunne, K., Arratia, P. \& Jerolmack, D. EarthArXiv (2019). URL https://eartharxiv.org/repository/view/849/.

215. Gray, J., Laronne, J. \& Marr, J. D. G. Bedload-surrogate monitoring technologies. U.S. Geological Survey Scientific Investigations Report 2010-5091, United States Geological Survey

216. Rickenmann, D., Turowski, J. M., Fritschi, B., Klaiber, A. \& Ludwig, A. Bedload transport measurements at the Erlenbach stream with geophones and automated basket samplers. Earth Surf. Process. Landforms 37, 1000-1011, DOI: 10.1002/esp.3225. (2012).

217. Wyss, C. R. et al. Measuring Bed Load Transport Rates by Grain-Size Fraction Using the Swiss Plate Geophone Signal at the Erlenbach. J. Hydraul. Eng. 142, 04016003, DOI: 10.1061/(ASCE)HY.1943-7900.0001090. (2016).

218. Beer, A. R., Turowski, J. M., Fritschi, B. \& Rieke-Zapp, D. H. Field instrumentation for high-resolution parallel monitoring of bedrock erosion and bedload transport. Earth Surf. Process. Landforms 40, 530-541, DOI: https: //doi.org/10.1002/esp.3652. (2015). 
219. Hsu, L., Finnegan, N. J. \& Brodsky, E. E. A seismic signature of river bedload transport during storm events. Geophys. Res. Lett. 38, DOI: 10.1029/2011GL047759. (2011).

220. Barrière, J., Oth, A., Hostache, R. \& Krein, A. Bed load transport monitoring using seismic observations in a low-gradient rural gravel bed stream. Geophys. Res. Lett. 42, 2294-2301, DOI: https://doi.org/10.1002/2015GL063630. (2015).

221. Roth, D. L. et al. Bed load sediment transport inferred from seismic signals near a river. J. Geophys. Res. Earth Surf. 121, 725-747, DOI: 10.1002/2015JF003782. (2016).

222. Dietze, M., Lagarde, S., Halfi, E., Laronne, J. B. \& Turowski, J. M. Joint Sensing of Bedload Flux and Water Depth by Seismic Data Inversion. Water Resour. Res. 55, 9892-9904, DOI: https://doi.org/10.1029/2019WR026072. (2019).

223. Masteller, C. C., Finnegan, N. J., Turowski, J. M., Yager, E. M. \& Rickenmann, D. History-Dependent Threshold for Motion Revealed by Continuous Bedload Transport Measurements in a Steep Mountain Stream. Geophys. Res. Lett. 46, 2583-2591, DOI: 10.1029/2018GL081325. (2019).

224. Reid, I., Frostick, L. E. \& Layman, J. T. The incidence and nature of bedload transport during flood flows in coarse-grained alluvial channels. Earth Surf. Process. Landforms 10, 33-44, DOI: https://doi.org/10.1002/esp.3290100107. (1985).

225. Pretzlav, K. L. G., Johnson, J. P. L. \& Bradley, D. N. Smartrock Transport in a Mountain Stream: Bedload Hysteresis and Changing Thresholds of Motion. Water Resour. Res. 56, e2020WR028150, DOI: https://doi.org/10.1029/2020WR028150. (2020).

226. Turowski, J. M., Badoux, A. \& Rickenmann, D. Start and end of bedload transport in gravel-bed streams. Geophys. Res. Lett. 38, DOI: https://doi.org/10.1029/2010GL046558. (2011).

227. Phillips, C. B. \& Scatena, F. N. Reduced channel morphological response to urbanization in a flood-dominated humid tropical environment. Earth Surf. Process. Landforms 38, 970-982, DOI: https://doi.org/10.1002/esp.3345. (2013).

228. Phillips, C. B. Lczo Geomorphology Stream channel geomorphology Puerto Rico (2009-2012). Hydroshare (2020). URL http://www.hydroshare.org/resource/b538d75e180a424ca38d54e28500d33e.

229. Ferguson, R. I. Flow resistance equations for gravel- and boulder-bed streams. Water Resour. Res. 43, 12 PP., DOI: 200710.1029/2006WR005422. (2007).

230. Lajeunesse, E., Malverti, L. \& Charru, F. Bed load transport in turbulent flow at the grain scale: Experiments and modeling. J. Geophys. Res. 115, 16 PP., DOI: 201010.1029/2009JF001628. (2010).

231. PRISM Climate Group. 30 year normal rainfall. Oregon State University (2021). URL http://prism.oregonstate.edu.

232. Dietrich, W. Eel River Critical Zone Observatory July 2014 Lidar Survey. National Center for Airborne Laser Mapping (NCALM). Distributed by OpenTopography. (2014).

233. USGS. LPC PA South Central B 2017 LAS Lidar Survey. National Center for Airborne Laser Mapping (NCALM). Distributed by OpenTopography. (2019).

\section{Acknowledgements}

We dedicate this paper to Gary Parker, whose brilliance and enthusiasm has touched nearly every aspect of this work. The idea for this manuscript developed out of conversations at the River, Coastal and Estuarine Morphodynamics (RCEM) 2019 symposium; we are grateful to the organizers H. Friedrich and K. Roisin Bryan for that stimulating forum. Work was supported by Army Research Office (Award Number W911NF2010113) and National Science Foundation (NSF), National Robotics Initiative Grant (Award Number 1734365) to D.J.J.

\section{Author contributions}

C.B.P. and D.J.J. developed the idea and structure of this Review, with input from all authors. All authors contributed to writing, data analysis and interpretation. 


\section{${ }_{973}$ Competing interests}

974 The authors declare no competing interests.

\section{${ }_{975}$ Publisher's note}

976 Springer Nature remains neutral with regard to jurisdictional claims in published maps and institutional affiliations. 


\section{Box 1: The threshold of motion constrains fluid stress through channel geometry}
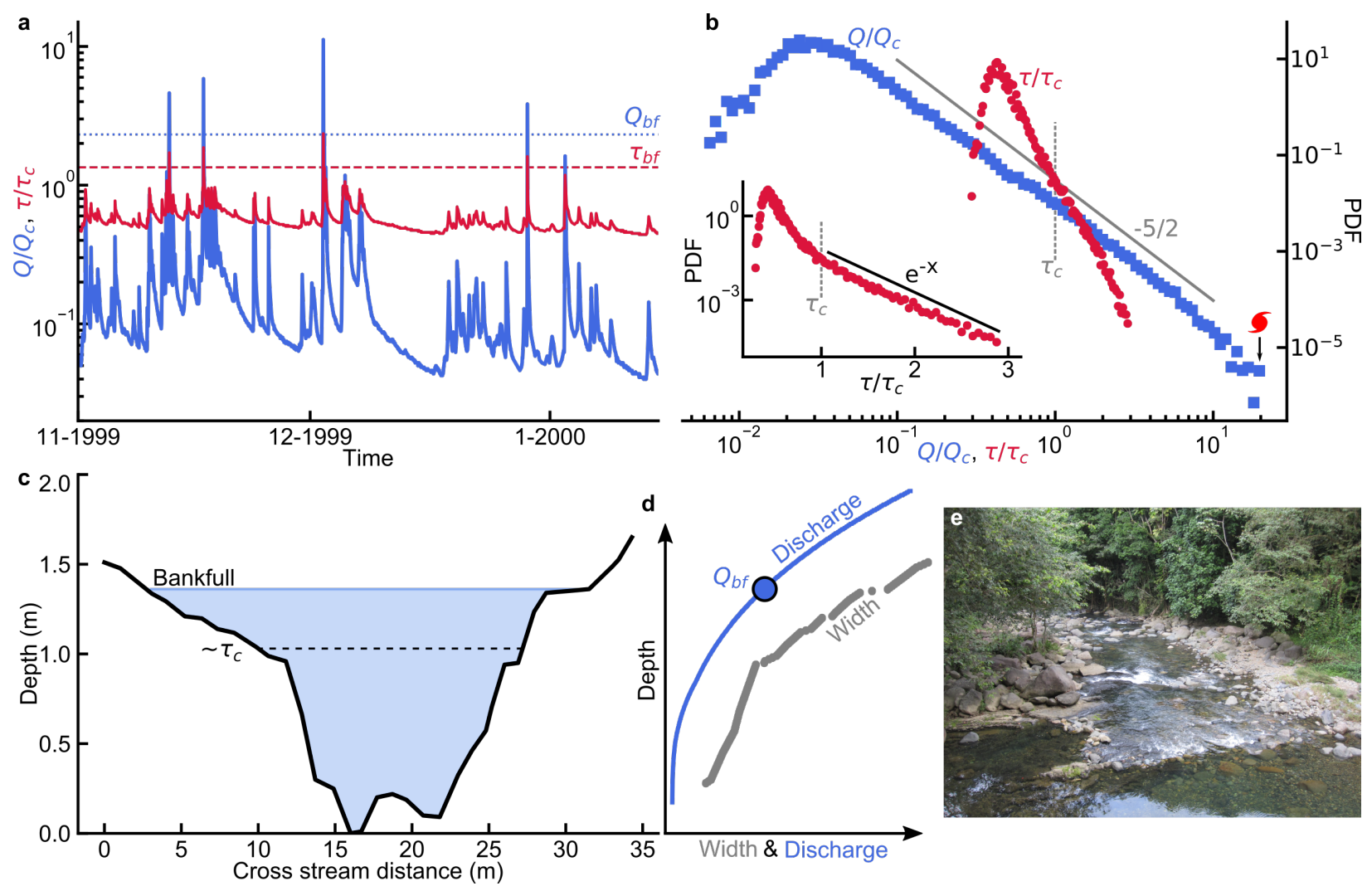

Box 1. The threshold of motion constrains fluid stress through channel geometry. a| Hydrograph for the Mameyes River (USGS gage 50065500) normalized by the threshold of motion. Due to frequent storms and steep topography the Mameyes floods frequently, note the occurrence of four bankfull floods (dashed and dotted lines) within two months during the dry season. $\mathbf{b} \mid$ Probability density functions (PDF) for discharge (blue squares) and shear stress (red circles) normalized by the threshold of motion (vertical dashed line) for Water years 1995-2020. The peak in each PDF represents baseflow, values greater than one indicate flows capable of transporting the bed material, and the highest flows are primarily hurricanes (red symbol) at values of $20 Q_{c}\left(3 \tau_{c}\right)$. Discharge beyond baseflow is well described by a power law with slope of $-5 / 2$, while shear stress contains a subtle scaling break at approximately $\tau_{c}$. The inset shows $\tau / \tau_{c}$ on a semi-log plot where a straight line represents an exponential function. $\mathbf{c} \mid$ Cross section of the Mameyes River ${ }^{227,228}$ with the approximate location of the threshold $\left(\tau_{c}\right)$ and bankfull indicated. d| Relations between depth and discharge (blue line) and width (gray points). These data share the same vertical depth scale as the cross section. The relation between depth and width is informative in understanding the relation between depth and discharge. Depth increases rapidly initially but gives way to increases in width as the cross section expands. e) Photograph of the section of the Mameyes River downstream of the gaging station where the cross section was measured (wetted width is $12 \mathrm{~m}$ across).

\section{Box 2: Application of the near-threshold model}

Box $2 \mid$ Given an imposed water $(Q)$ and sediment $\left(Q_{s}\right)$ discharge, the bankfull geometry of a natural channel can be designed with the threshold-limited model through the following five relations. Conservation of mass for the fluid yields the bankfull discharge:

$$
Q_{b f}=U_{b f} H_{b f} W_{b f},
$$


where $U_{b f}, H_{b f}$, and $W_{b f}$ are the bankfull flow velocity, width and depth, respectively. Conservation of momentum under the assumption of normal flow provides the bankfull shear stress $\left(\tau_{b f}\right)$ through the depth-slope product:

$$
\tau_{b f}=\rho g H_{b f} S
$$

Velocity is related to shear stress through a flow resistance equation:

$$
U_{b f}=C_{f} \sqrt{\tau_{b f / \rho}}
$$

Here we present a Darcy-Weisbach flow resistance equation, though one could use any number of relations ${ }^{229}$. The coefficient of flow resistance $C_{f}=\sqrt{8 / f}$, where $f$ is the Darcy-Weisbach friction factor. Sediment flux can be approximated through a bed-load flux equation:

$$
Q_{s}=k\left(\tau_{b f}-\tau_{c}\right)^{3 / 2} W_{b f},
$$

where $\mathrm{k}$ is a fitting coefficient and $\tau_{c}$ is the sediment threshold entrainment stress. Similar to flow resistance, a myriad of bed-load flux equations ${ }^{78,230}$ exist depending on the sediment grain size and distribution. The choice of equation may depend on the practitioner's situation. The $1+\varepsilon$ model provides the final relation required to close this set of hydraulic equations by relating the threshold of sediment entrainment to the bankfull shear stress:

$$
\tau_{b f}=(1+\varepsilon) \tau_{c}
$$

For the following derivations, we set $\varepsilon=0.2$ as it provides good predictions for natural rivers ${ }^{6,52,66}$. We note, however, that other values are possible and depend on the formulation for the lateral transfer of downstream momentum and the choice of flow resistance relation in the derivation of the $1+\varepsilon$ model. These five equations can be rearranged to provide solutions for the bankfull width and depth:

$$
W_{b f}=\frac{g Q S}{C_{f}\left(\frac{1.2 \tau_{c}}{\rho}\right)^{3 / 2}}
$$

and

$$
H_{b f}=\frac{1.2 \tau_{c}}{\rho g S}
$$

The slope of a reach is often considered an imposed condition, however with an imposed water and sediment discharge equations (2) and (4) can be rewritten to solve for the river slope:

$$
S=\frac{6}{\rho g H_{b f}}\left(\frac{Q_{s}}{k W_{b f}}\right)^{2 / 3} .
$$


1007 These equations may be an oversimplification of the vast number of variables at play within a river corridor, however they 1008 provide a physically rational set of relations consistent with natural rivers and laboratory channels to estimate the average 1009 channel geometry. 

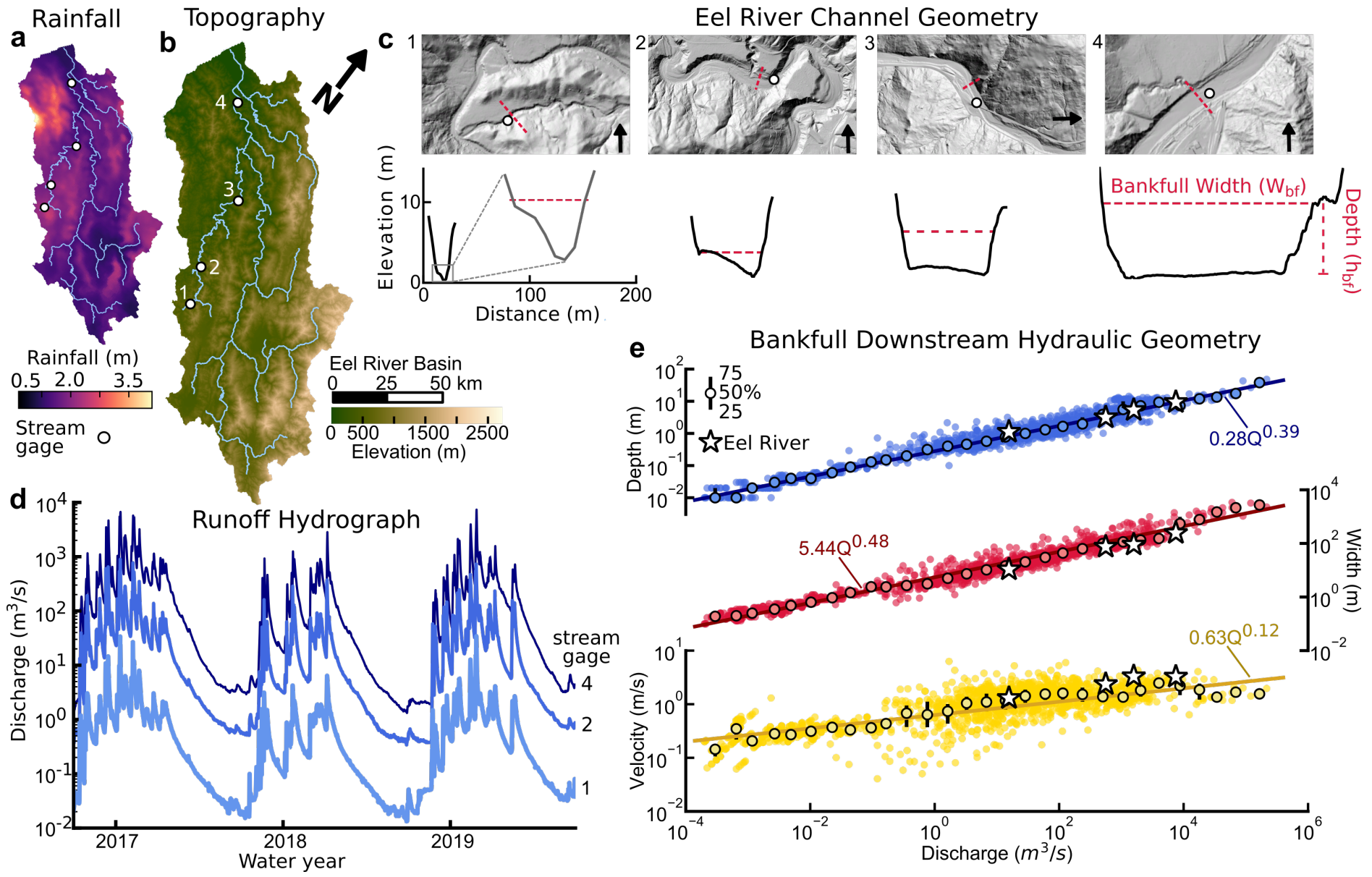

Figure 1. Downstream hydraulic geometry within a catchment. a| Annual precipitation ( 30 year normals ${ }^{231}$ ) within the Eel River watershed. $\mathbf{b} \mid$ Topography of the Eel River watershed. $\mathbf{c} \mid$ (top row) High resolution lidar hillshade ${ }^{232}$ showing USGS gage and cross section locations. The scale is the same for each image. (bottom row) Cross sections near the gaging sites. The size of the channel grows considerably as drainage area and discharge increase downstream. The bankfull width (red dashed line) is labelled on each cross section. $\mathbf{d} \mid$ Runoff hydrographs for three gages (labeled 1,2, and 4). Notice that in this watershed the shape of the hydrographs changes minimally between upstream and downstream, but gains considerable flow. $\mathbf{e} \mid$ Bankfull downstream hydraulic geometry (width, depth, and velocity) for 1,652 rivers (small points) ${ }^{110}$. The best fit power relations are fit to the binned median values (large circles). Error is shown through the interquartile range and is typically smaller than the plotting symbol. The stars represent the four gages from the Eel River. (top row) Bankfull depth scaling against discharge. (middle row) Bankfull width scaling against discharge. (bottom row) Bankfull velocity scaling against discharge. Here the velocity $U_{b f}=Q_{b f} /\left(W_{b f} H_{b f}\right)$. Velocity shows considerably more scatter than either width or depth data, but is also not independently measured. The fitted trend lines are remarkable in that they provide first order approximations for river hydraulic geometry across 10 orders of magnitude in discharge. 


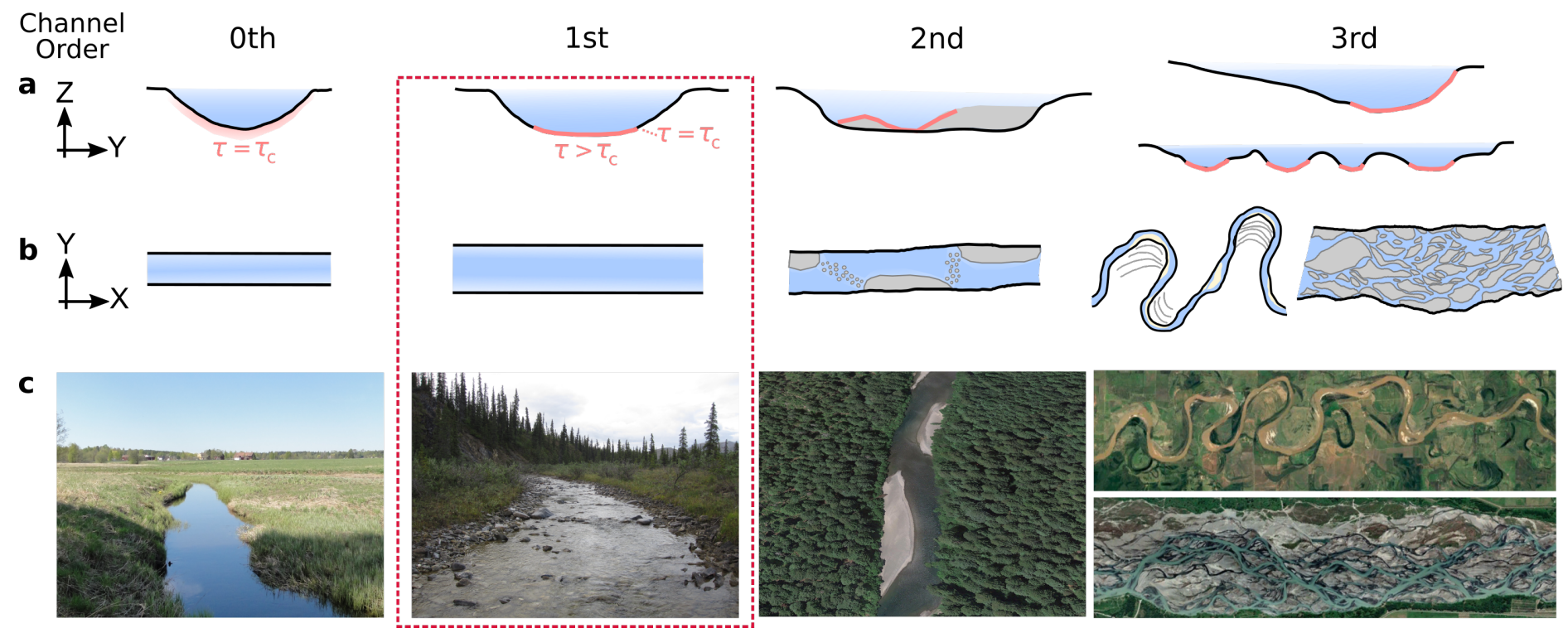

Figure 2. Schematic illustration of the proposed orders of channel behavior. a| Schematic channel cross sections representing the orders of channel behavior from left to right: a threshold channel, near-threshold channel, channel with morphology, and meandering or braided morphology. The red dashed box represents the 1st order near-threshold channel that is the focus of this review. Light red regions represent regions of the channel at or above the threshold of motion. $\mathbf{b} \mid$ Planform or map view of the channel cross sections. c| Photographs and satellite images of (from left to right) a grass lined canal in Sweden, a cobble river in Alaska, the Eel River with alternating bars in California, and meandering and braided rivers in Indiana (USA) and New Zealand, respectively. The photo of the canal is courtesy of B. Neilson, and the alternate bar, meandering and braided rivers are from Google Earth. 

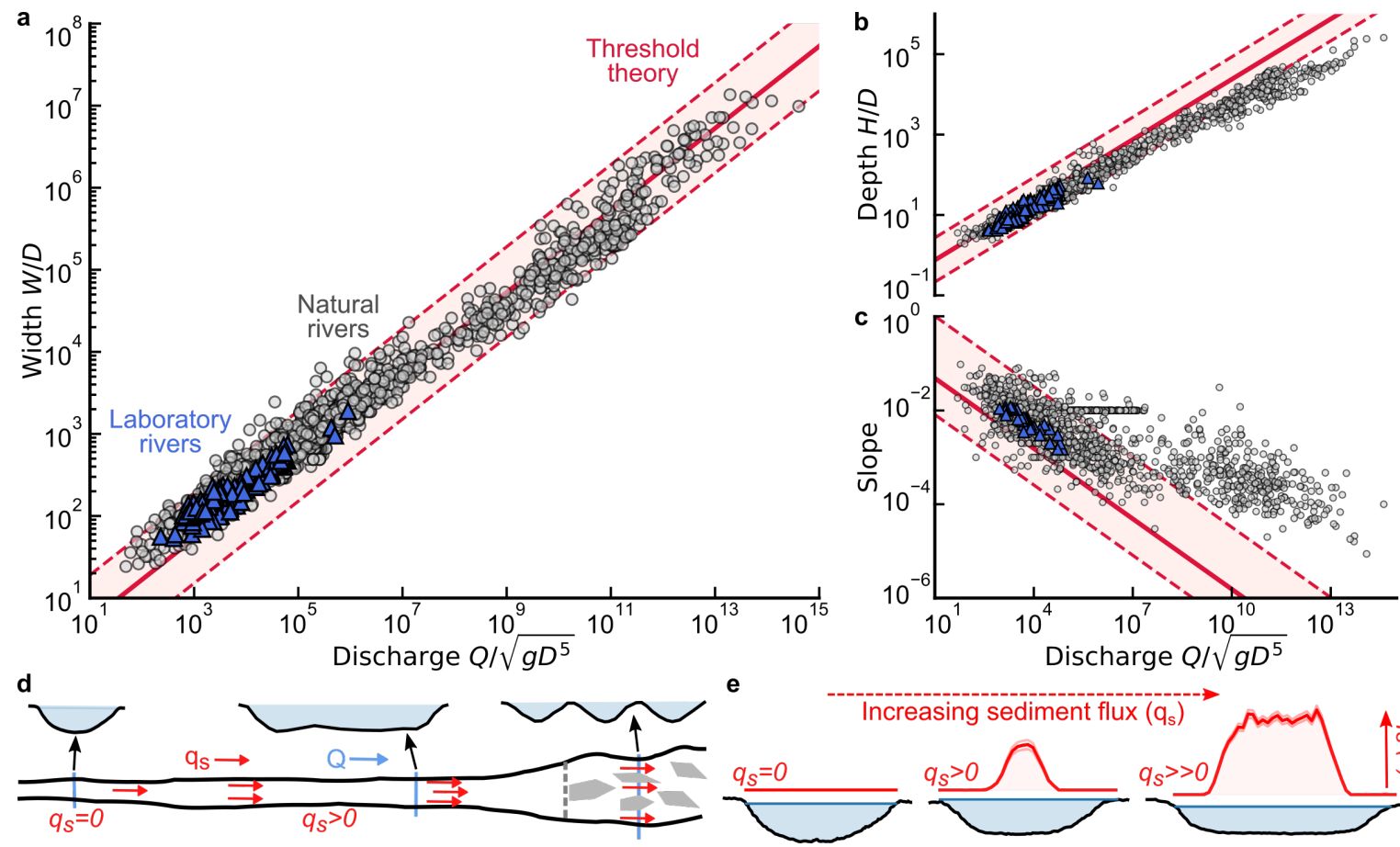

creasing sediment flux $\left(\mathrm{q}_{\mathrm{s}}\right)$

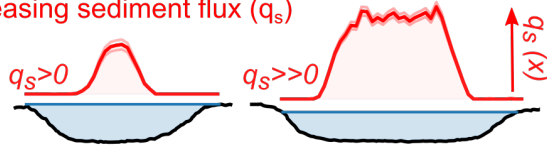

Figure 3. The width of natural and laboratory alluvial rivers follow near threshold predictions. a| Natural (1,581 gray points $\left.{ }^{110}\right)$ and laboratory alluvial rivers ${ }^{53}$ dimensionless width $\left(W / D_{50}\right)$ and discharge scaling compared with threshold theory (red line represents a threshold channel with $\tau_{c}^{*}=0.05$ and $C_{f}=0.1$ ). Both data sets sit slightly offset from the threshold theory. The shaded area denotes uncertainty within the possible parameter estimates for a threshold channel. $\mathbf{b} \mid$ Dimensionless depth $\left(H / D_{50}\right)$ against dimensionless discharge. Fine-grained rivers are significantly shallower than threshold theory predicts. c| River slope against dimensionless discharge. The threshold channel is less steep than coarse-grained rivers and significantly lower gradient than fine-grained rivers. $\mathbf{d} \mid$ Schematic of the evolution of a transient experimental channel illustrating the transition from threshold, to increasing sediment flux to the point of channel instability. The early experiments of Stebbings ${ }^{115}$ illustrate the end member conditions of single thread alluvial channels and the importance of sediment flux. e| Recent experimental efforts under laminar flow conditions directly measure the influence of increasing sediment flux on channel geometry ${ }^{51}$. From left to right, under no sediment flux $\left(q_{s}=0\right)$ and constant discharge the channel cross section nearly exactly matches the cosine prediction from threshold theory, increasing sediment flux (middle and right) drives a stark increase in channel aspect ratio $(\mathrm{W} / \mathrm{H})$ and a steepening of the channel banks. 

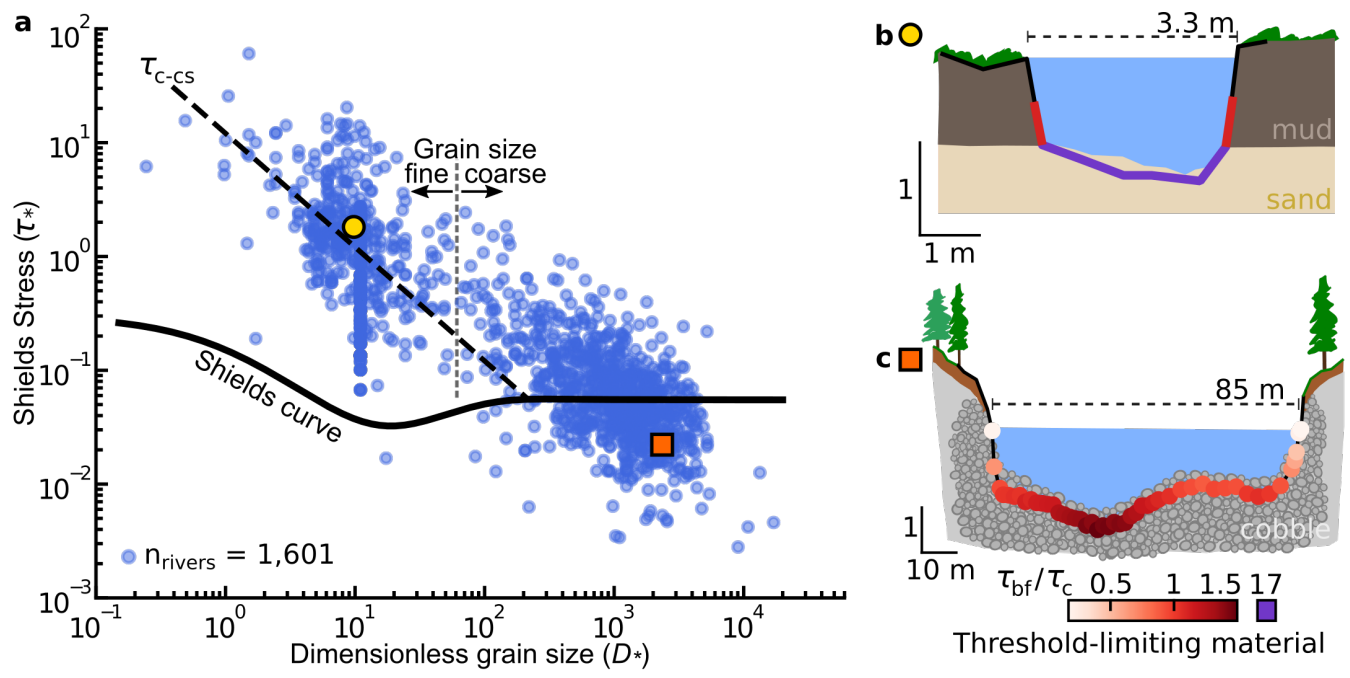

Figure 4. Shields diagram and illustrations of the near-threshold and threshold limiting models. a| Variation of bankfull dimensionless shear stress (Shields stress) with dimensionless grain size. The compiled rivers create two clouds of data between coarse and fine-grained rivers (dotted vertical line is $2.5 \mathrm{~mm}$ ). The coarse grained rivers cluster near the threshold of motion as defined by the Shields curve, while fine-grained rivers cluster about the average threshold for clay sand mixtures $\left(\tau_{c-c s}\right.$, dashed diagonal line). $\mathbf{b} \mid$ Illustration of the threshold-limited model for the Mullica River (yellow circle), a fine-grained river with cohesive banks. The black line represents the surveyed cross section. The cohesive banks (mud) are near the threshold at the channel center $\left(\tau_{b f} / \tau_{c}=1.13\right)$, while the fine-grained bed material (sand) is well above its respective threshold of motion $\left(\tau_{b f} / \tau_{c}=17\right)$. c Illustration of the near-threshold model for a surveyed cross section (black line) the Salmon River, a cobble lined river in rural Idaho. Surveyed points below the bankfull flow are shaded according to the bankfull transport capacity (average $\tau_{b f} / \tau_{c}=1.17$ ). Shear stresses are computed via the depth slope product using the hydraulic radius due to the narrow channel aspect ratio for the Mullica River and using the local depth for the Salmon River. 


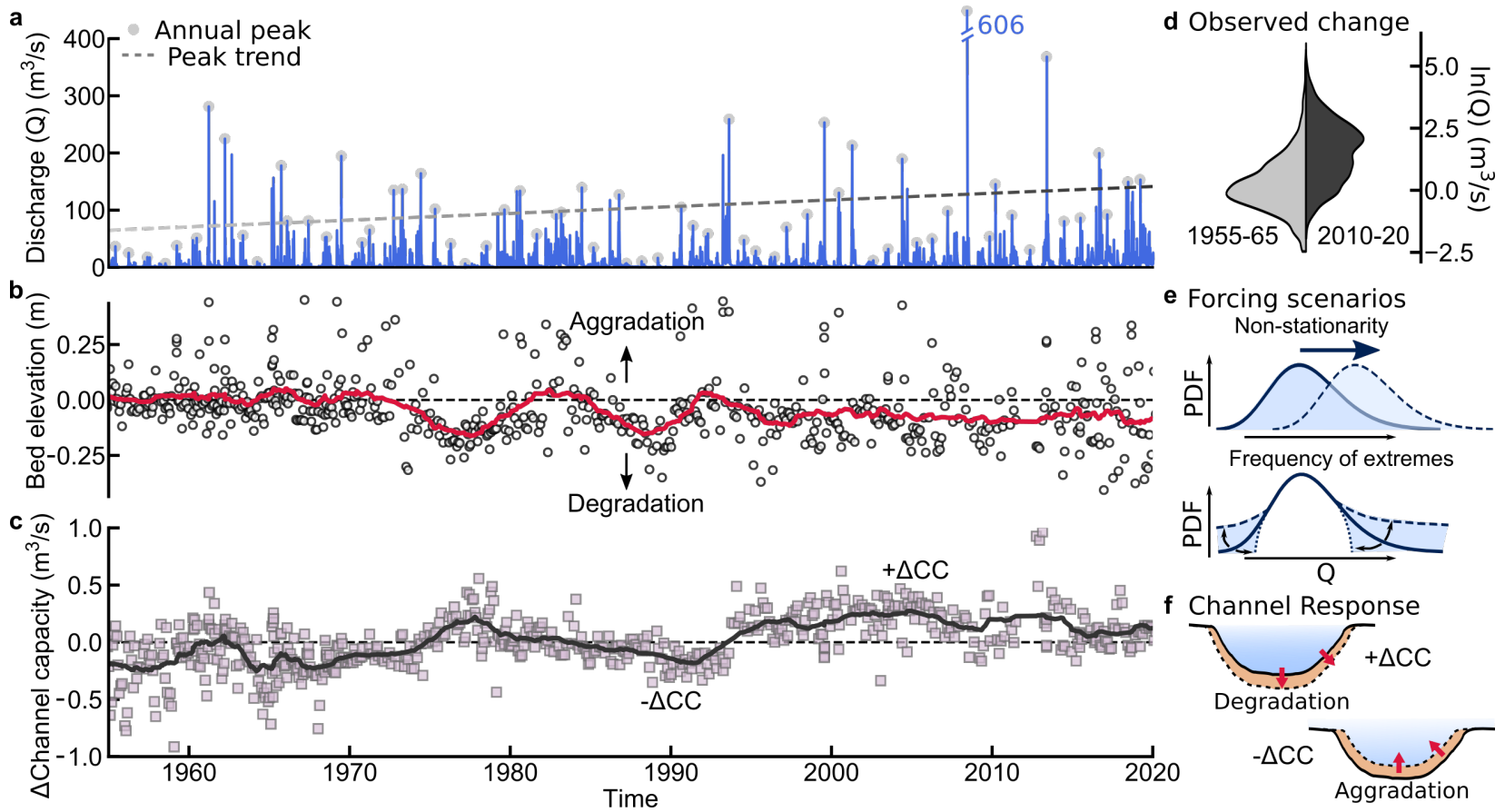

Figure 5. River channel size grows and shrinks in response to hydroclimatic cycles and persistent changes in hydroclimate. a| Daily mean discharge $(Q)$ records from 1955-2020 for Little Cedar River near Ionia, Iowa, USA (Gage No. 05458000). At this gage the annual peak flow (gray circles) has increased over time (dashed trend line). Periodicity within the discharge record is correlated with the Arctic Oscillation ${ }^{109} . \mathbf{b} \mid$ Mean bed elevation measurements over time showing a gradual degradation of the bed. The rolling average (red line) highlights periods of persistent scour or fill relative to the start of the record (dashed black line). $\mathbf{c} \mid$ Changes in flood stage channel capacity $\left(\triangle C C, \mathrm{~m}^{3} / \mathrm{s}\right)$ over time. Increases in discharge were accommodated by channel bed degradation resulting in increased channel capacity since the 1950s. The rolling average (black line) represents periods of increased/decreased channel capacity relative to the average stage-discharge rating curve. d| Observed change in discharge frequency between the initial (1955-65, light gray) and final (2010-20, dark gray) ten years of the record. The probability density functions (PDF) are represented by the kernal density estimates of the natural log-transformed discharge data and show an overall shift in the discharge distribution. e| Potential statistical changes within the discharge record (non-stationarity) as a result of changes in landuse or hydroclimate include a shift in the mean and/or the frequency of extreme values. These changes result in differing forcing scenarios for channel adjustment. $\mathbf{f} \mid$ Schematic showing increases in channel capacity (conveyance) through degradation, increased widening and/or declining roughness (i.e., $\tau_{b f}$ ), and decreases through aggradation, narrowing and/or increasing roughness. 

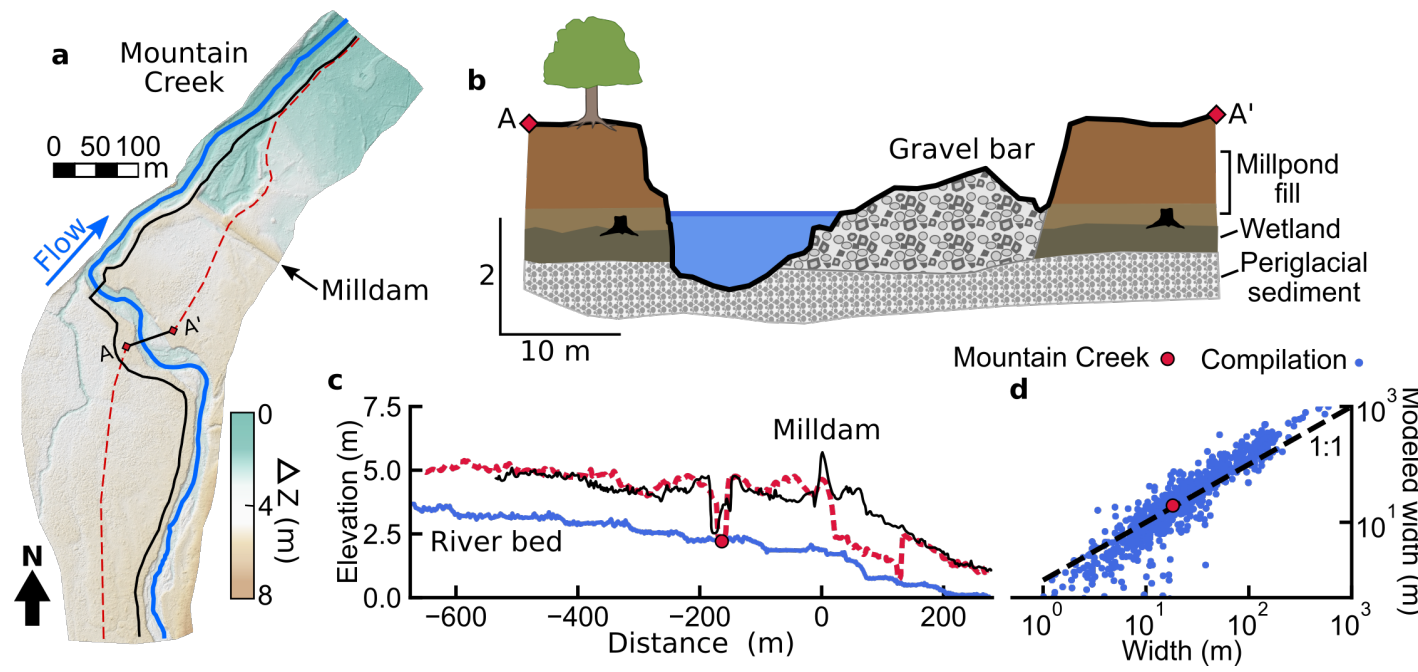

Figure 6. Historic land use can alter river geometry over long timescales. a| Lidar topography of Mountain Creek near Mt. Holly Springs, $\mathrm{PA}^{233}$. The presence of a historic milldam resulted in reduced flow velocities and significant upstream sediment deposition. The resulting deposition can be seen in the elevation difference $(\Delta Z)$ above and below the breached dam. The traced lines represent the longitudinal profiles shown in $\mathbf{c}$. $\mathbf{b} \mid$ Cross section of Mountain Creek showing buried precolonial wetland sediment characterized by relic tree stumps and wetland vegetation. The increased mobile sediment following the breach of the dam resulted in rapid incision down to the coarser periglacial sediment below. Modern inset gravel bars are a result of current sediment mobility. $\mathbf{c} \mid$ Longitudinal profiles of the modern river bed (blue) and two profiles (black solid and red dashed lines) showing the elevation up and downstream of the milldam. $\mathbf{d} \mid$ Modeled bankfull width for Mountain Creek (red circle) and coarse-grained rivers $\left(D_{50}>5 \mathrm{~mm}\right.$, blue points) from the data compilaiton ${ }^{110}$. The $1+\varepsilon$ model provides an accurate prediction of the modern channel width based on the periglacial sediment diameter $\left(D_{50}=68 \mathrm{~mm}\right)$ indicating that the current channel is well described by the near-threshold model. Modeled predictions follow from Box 2, with a coarse-grained river average $C_{f}=7$ and $\tau_{c}=\tau_{b f} / 1.2$. The misalignment at low and larger widths for the compilation is a consequence of the use of a single value for $C_{f}$. 


\section{Glossary terms}

- sediment: particulate material that has been moved and deposited by some natural process

- water discharge: the flow rate of water measured in terms of volume per unit time

- entrainment: dislodging of grains from the surface of a sediment bed by a current

- fluvial geomeorphology: study of the form and process of rivers

- bankfull: the flow which brings a river to the brink of overbank flooding

- universality: robust statistical or scaling properties that are independent of system details

- dimensionless: groupings of variables that have no units, often used to reduce the number of free parameters

- morphodynamic: the feedback between (fluid) flow and (bed-surface) form that evolves landscape patterns

- braided rivers: channels with myriad bars that divide flow into numerous smaller (and typically unstable) threads

- stationary: behavior or process that does not depend on time

- singular perturbation analysis: mathematical approach for problems containing a small parameter that cannot be approximated by setting the parameter value to zero

- bed load: fluid-driven motion of particles that are in close contact with, and are supported by, the bed

- mud: wet particulate mixture with significant cohesion, typically from clay and/or organics

- form drag: the portion of fluid momentum that is dissipated by (turbulent) interaction of the flow with the bed

- closure scheme: a parameterized relation among two (or more) variables that closes a set of equations, allowing a unique solution

- parameterization: representing a complex process with a simpler mathematical expression, or constant parameter, for the purposes of modeling 